\title{
Het Belgische tijdschrift Grafiek en de katholieke interpretatie van de modernistische typografie tijdens de jaren dertig en veertig
}

\author{
Katrien van Haute
}

\section{ABSTRACT}

Grafiek (1936-2000) was a Belgian graphic arts periodical published by KOLVO, the alumni union of the 'Kunstdrukschool Sint-Lucas' in Ghent. Focusing on the first 25 issues (1936-1948) this article is a first investigation of how the graphic style evolved at this school during the early period of the modern graphic design. Leading man of both the Kunstdrukschool and Grafiek was friar Jan Peeters, who tinkered a design method that served as a pedagogical instrument. His method was inspired (directly or indirectly) by the writings of modernist pioneers such as Jan Tschichold. For a Catholic designer in Belgium in the early twentieth century, shaping the new profession of the graphic designer that combined progressive (modernist) aesthetics with deep religious Catholic incentives clearly was a struggle.

De modernistische grafische vormgeving, die tijdens het interbellum het levenslicht zag, was een reactie op de kwaliteitsontwaarding van het traditionele drukwerk. De drukker kreeg kritiek omdat hij te vaak op automatische piloot vloog en tot in den treure dezelfde formules herhaalde. Doorgaans gunde hij zichzelf geen enkele artistieke vrijheid, tenzij het op de ornamenten aankwam. Dat aanbod was quasi onbeperkt: letterproeven uit die periode bulken uit van de fleurons, culs-de-lampe, borduren en fileten. ${ }^{1}$

In de geschiedschrijving van de grafische vormgeving gaat het verhaal dat de reactie op genoemde kwaliteitsontwaarding niet uit eigen rangen kwam, maar van buitenaf. De pioniers van het grafische ontwerp waren beeldend kunstenaars en dichters die de bijl zetten aan de wortel van de oude eik van zekerheden en voorspelbaarheid die de drukkunst geworden was. László Moholy-Nagy, El Lissitzky, Kurt Schwitters, Alexander Rodchenko, Theo Van Doesburg en vele anderen verlieten in hun ontwerpen de axiale lay-out en experimenteerden met schreefloze lettertypes en een asymmetrische vlakverdeling. De witte onbedrukte ruimte die door een asymmetrische bladschikking vaak prominent in beeld komt, werd niet langer gezien als een ondergeschikte restvorm die in de achtergrond verdwijnt, maar als een positief beeldelement in het ontwerp. ${ }^{2}$
Zo zou men, in een notendop, de aardverschuiving uit het begin van de twintigste eeuw kunnen samenvatten. Deze geschiedenis, ook wel de 'pionierstijd van de grafische vormgeving' genoemd, wordt voor het eerst opgetekend in 1928 door Jan Tschichold, ontwerper én auteur van diverse publicaties over typografie. Tschicholds weergave van het ontstaan van de grafische vormgeving is door veel auteurs gevolgd. Herbert Spencer bijvoorbeeld volgt in 1969 in zijn invloedrijke Pioneers of Modern Typography nog steeds (grosso modo) Tschicholds analyse en bleef ook trouw aan diens selectie van illustratieve beelden. ${ }^{3}$ Sindsdien hebben verschillende auteurs geprobeerd een alternatief te formuleren voor dit canon van telkens dezelfde ontwerpen in een bepaalde coherente historische logica. Maar zoals Robin Kinross terecht opmerkt, kan een onderzoeker hieraan moeilijk ontsnappen aangezien het materiaal dat de ontwerphistoricus ter beschikking staat bijzonder beperkt is. ${ }^{4}$

Zo komt het dat de geschiedenis van het twintigste-eeuwse grafische ontwerp meestal wordt bekeken vanuit een kunsthistorisch standpunt met de ontwerper als een 'auteur', een vrije kunstenaar die zich niet met verf en penseel op het doek uitdrukt maar expressie geeft aan zijn individuele opvattingen en emoties aan de hand van drukinkt en typografie. De druksels van Hendrik Nicolaas Werkman of Kurt Schwitters kunnen misschien wel worden vergeleken met de schilderijen of beeldhouwwerken van tijdgenoten, maar voor de meeste grafische ontwerpers was de realiteit totaal anders. Zij werkten in opdracht en genoten niet diezelfde totale vrijheid.

Vraag vandaag aan een student grafische vormgeving wat hij of zij zich voor de geest haalt denkende aan de jaren dertig en veertig, dan zullen de namen László Moholy-Nagy en Jan Tschichold wellicht vallen, terwijl het eerder onwaarschijnlijk is dat een gewone burger uit die tijd met hun werk in contact is gekomen. De ontstaansgeschiedenis van het moderne grafische ontwerp is met andere woorden een al te eenzijdig relaas en zal onvolledig blijven zolang het niet wordt aangevuld met een onderzoek geschreven vanuit het standpunt 
van de drukkers, zetters en typografen. Want het waren uiteindelijk deze ambachtslieden die, meestal anoniem, het moderne grafische ontwerp ingang deden vinden in het dagelijkse leven. Aangestoken door de modernisten volgden zij niet langer slaafs de vastgeroeste voorschriften van het drukkersambacht. Vanaf de jaren dertig streefden ze ernaar om voor elk druksel dat de drukkerij verliet de meest geschikte vorm te vinden. Zij werden met andere woorden 'vormgever' en waren in zekere zin de wegbereiders van wat we tegenwoordig 'grafische ontwerpers' noemen.

\section{HET TIIDSCHRIFT GRAFIEK EN DE PEDAGOGIE VAN JAN PEETERS: GIDS VOOR EEN NIEUWE LICHTING GRAFI- SCHE VORMGEVERS IN BELGIË}

Hoewel deze talrijke drukkers, zetters en typografen in vergelijking met de modernistische avant-garde kunstenaars een veelvoud aan drukwerk produceerden, konden hun ontwerpen toch nauwelijks het trieste lot van de papiermand ontlopen. Banaal efemeer drukwerk wordt ook vandaag nog zelden systematisch gearchiveerd.

Dit maakt de twintigste-eeuwse vaktijdschriften voor drukkers of grafische ontwerpers zulke rijke studieobjecten. Ze herbergen niet alleen die zeldzame ontwerpen maar geven daarenboven informatie over de context van de ontwerpersgemeenschap waarin ze tot stand kwamen. Tegelijk kan men ook aannemen dat een ontwerperstijdschrift op zijn beurt veel invloed uitoefende op de abonnees en mee de grafische identiteit van een groep vormgaf. Dit geldt des te meer voor tijdschriften uitgegeven door een school voor grafische vormgeving. De Duitse Bauhausbücher zijn daar wellicht het bekendste voorbeeld van.

In België liep van 1936 tot 2000 het tijdschrift voor grafische vormgeving genaamd Grafiek, 5 uitgegeven door de oud-leerlingenbond van de Gentse Kunstdrukschool Sint-Lucas. ${ }^{6}$ Dit tijdschrift sloot nauw aan bij het programma van de school. Vergelijkt men de inhoudsopgaven van de eerste 25 nummers (mijn onderzoek beperkt zich tot de eerste twaalf jaargangen) met de lesinhouden van de cursussen, dan kan men constateren dat er een grote overlap bestaat. Dat kan ook moeilijk anders aangezien zo goed als alle bijdragen werden geschreven door de docenten en de oud-studenten. Slechts in uitzonderlijke gevallen werkte de redactie van Grafiek samen met andere instellingen, nam ze een tekst van elders over of kwam er een externe auteur aan het woord. Grafiek geeft met andere woorden een rechtstreekse inkijk in de pedagogie van de Kunstdrukschool Sint-Lucas, een school met een grote historische waarde, alleen al omwille van het feit dat het de oudste Belgische opleiding is voor grafische vormgeving onderwezen in de Nederlandse taal. ${ }^{7}$ We weten bovendien met zekerheid dat alle studenten van de school op Grafiek geabonneerd waren (dat was immers verplicht) en dat ook heel wat oud-studenten een nummer toegestuurd kregen. $^{8}$

Grafiek onderscheidde zich van Belgische drukkerstijdschriften als La Chronique Graphique of Graphica omdat de redactie meer deed dan enkel drukwerk tonen van excellent niveau of berichten over de laatste technologische snufjes in de drukkerswereld. Het tijdschrift wilde zijn lezers ook vormen op vlak van wat we de 'theorie van de grafische vormgeving' zouden kunnen noemen, de bres breken voor de identiteit van de 'grafische vormgever' als virtuoze ambachtsman en zich zelfs inzetten voor diens arbeidsvoorwaarden. De docent Jan Peeters (broeder Zephirijn), die lesgaf vanaf het eerste uur in 1926 en ook na zijn opruststelling actief bleef in de bibliotheek en het archief tot aan zijn dood in 1992, speelde in het tijdschrift maar ook in de ontwikkeling van de Kunstdrukschool een centrale rol.

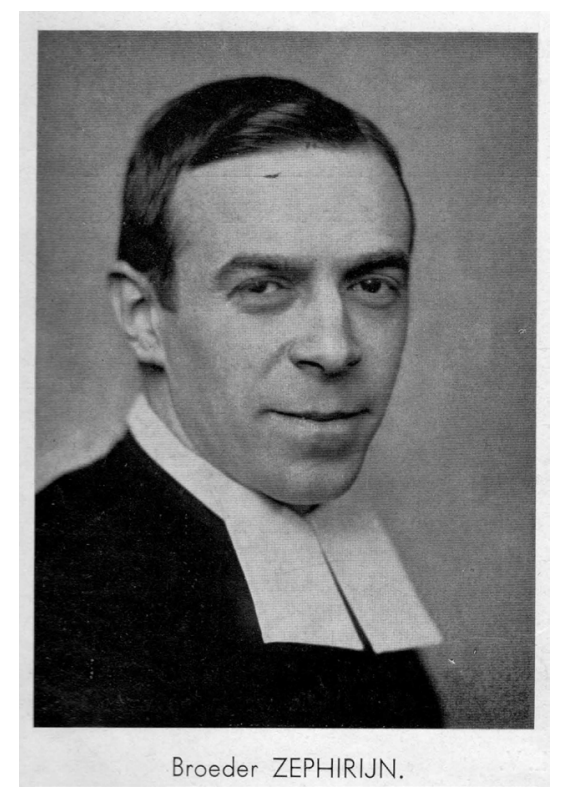

Portret Jan Peeters (broeder Zephirijn), Grafiek, no. 1 (1936).

Dat maakt hem voor dit onderzoek een waardevol figuur: dankzij zijn schrijfsels wordt het mogelijk om meer inzicht te krijgen in de methodes die de vormgevers van Grafiek hanteerden en wat de achterliggende motieven waren om bepaalde ontwerpkeuzes al dan niet te maken.

Het onderwijs van Jan Peeters en de Kunstdrukschool was katholiek van aard en dus niet ideologisch neutraal. Het tijdschrift Grafiek geeft dus ook een inkijk in de wijze waarop een hele generatie katholieke grafische vormgevers in Vlaanderen leerde 
omgaan met modernistisch drukwerk. Dit artikel presenteert de resultaten van een eerste verkennende studie naar het tijdschrift Grafiek met als focus de vragen: hoe de (ogenschijnlijk) modernistische attitude van het tijdschrift Grafiek te rijmen valt met het anti-moderne karakter van de Sint-Lucasscholen; en hoe in het tijdschrift de nieuw professie van de grafische vormgever gestalte krijgt.

\section{EEN VERRASSEND OPEN HOUDING TEGENOVER MODERN GRAFISCH ONTWERPEN}

Het Sint-Lucasonderwijs - eerst in Gent en later ook in Brussel, Namen, Doornik, Bergen en Luik - was het katholieke antwoord op de 'goddeloze' officiële kunstacademies die de maatschappij aan het ontkerstenen waren. De Sint-Lucasscholen moeten eigenlijk begrepen worden als religieuze academies.' Dit is typisch voor de Belgische 'verzuiling' van het onderwijs. ${ }^{10}$ Gedreven door hun romantisch ideaalbeeld van de middeleeuwen (in navolging van de Engelse architect Pugin) grepen de stichters van de Sint-Lucasscholen terug naar de vormentaal van de gotiek en organiseerden ze hun onderwijs in corporatistische ateliers. De neogotiek werd aldus dé stijl van het Sint-Lucasonderwijs en groeide in België zelfs uit tot de architectuur van de katholieken zondermeer.

Van de Sint-Lucasscholen is bekend dat moderne kunst en architectuur er geen vruchtbare bodem vonden zolang de school bestuurd werd door de congregatie van de Broeders van de Christelijke scholen (1866-1966). Hoewel de scholengroep met haar snelgroeiende studentenaantallen institutioneel een succes was, miste het artistiek gezien in het begin van de twintigste eeuw de boot van de moderniteit. Dat de neogotiek een obstakel bleek voor de modernisering van hun kunst en onderwijs werd lang betwist in eigen rangen, maar in 1955 kwam het Congres der Hogere Sint-Lucas instituten uiteindelijk zelf tot dit inzicht."

Wie echter het tijdschrift Grafiek doorbladert, ziet niet diezelfde gecrispeerde houding tegenover de moderniteit. Integendeel, het tijdschrift kenmerkt zich door een uitgesproken vooruitgangsoptimisme, niet alleen op druktechnisch vlak maar ook qua vorm lijkt het tijdschrift modernistisch. De redactie omarmde nieuwe lettertypes en promootte moderne ontwerpschema's, en nog het allervurigst de revolutionaire asymmetrische lay-out. De vraag is hoe deze attitude te rijmen valt met de anti-moderne neogotische geest van Sint-Lucas.

Om dit vraagstuk correct te kunnen beantwoorden, moet eerst de geschiedenis van de Kunstdruk- school minimaal toegelicht worden. Officieel was de Kunstdrukschool geen autonome school maar een opleiding binnen de afdeling Sierkunst van Sint-Lucas Gent. Daarom ging ze aanvankelijk ook onder deze vlag door het leven. In de praktijk had de opleiding echter een eigen directie, een eigen gebouw (de oude danszaal Parnassus in de Oude Houtlei, vlakbij de 'hoofdzetel' Sint-Lucas in de Zwarte zustersstraat) en zelfs een eigen broedercommunauteit.

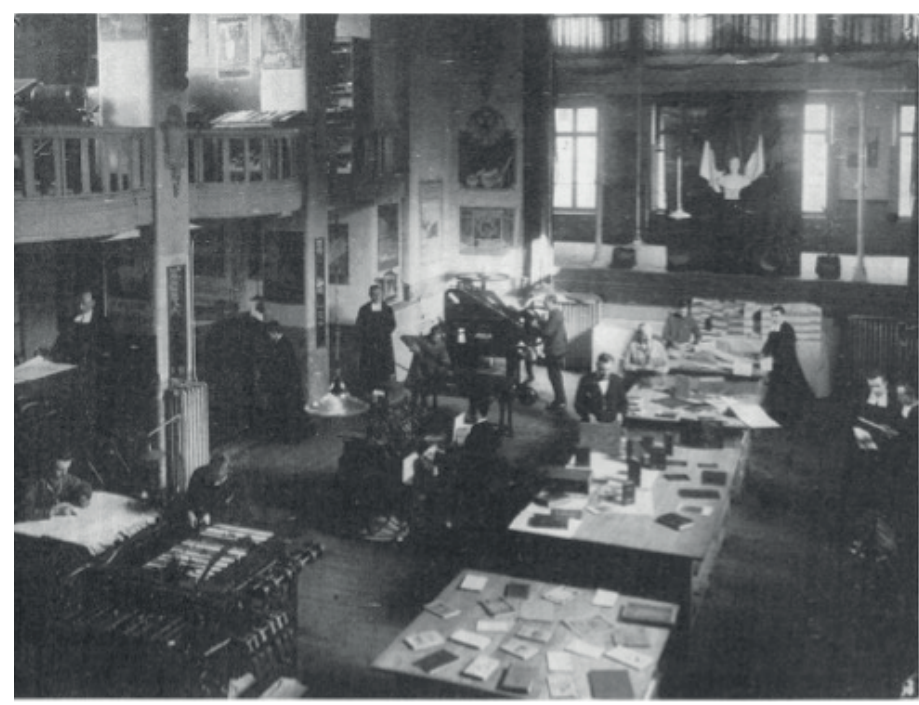

Kunstdrukschool Sint-Lucas, Parnassus, 26 februari 1929 (Foto archief Erik Dekeyser).

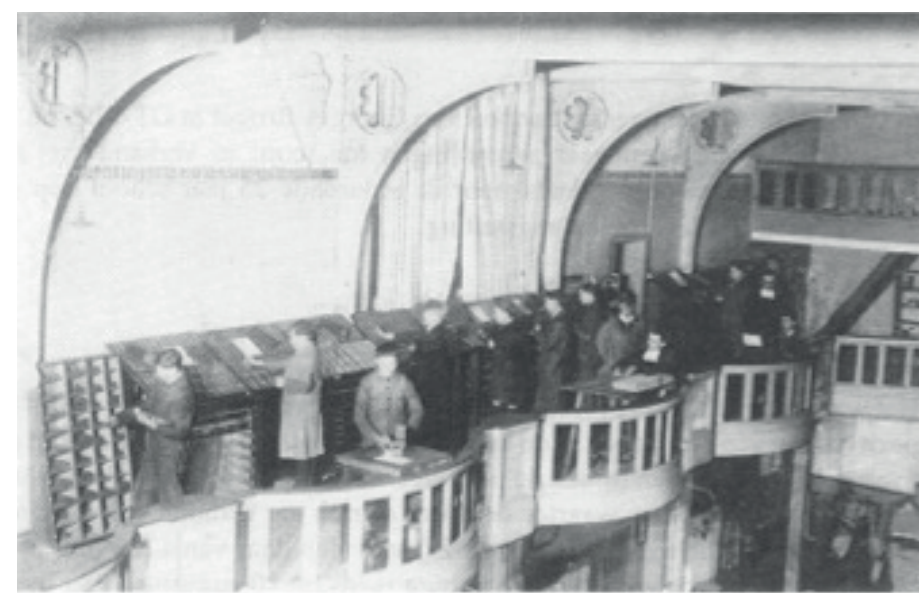

Het zijbalkon van de Parnassusfeestzaal waar de handzetterij was ondergebracht, ${ }_{1933}$ (Foto archief Erik Dekeyser).

Geleidelijk aan had de Kunstdrukschool steeds minder te maken met Sint-Lucas en ging ze haar eigen weg. Om verwarring te vermijden werd de school in 1933 dan ook omgedoopt tot Kunstdrukschool Onze-Lieve-Vrouw (KOLV).

De meer open houding van de Kunstdrukschool vloeit mijns inziens ten dele voort uit het wezen van het reclamedrukwerk, de spil van hun onderwijs. Omdat het reclameontwerp nog een vrij jonge discipline was in het drukkersvak, was het nog niet te veel door traditie belast. Reclamedrukwerk kon nog niet zoals de architectuur of het boekvorm- 
geving terugblikken op een lange en rijke geschiedenis. De verleiding om in een historische stijl zoals de neogotiek te ontwerpen lag dan ook niet voor de hand. Dat de reclameontwerper veel vrijer was dan de doorsnee boekvormgever, was overigens ook de gangbare mening in Grafiek. Men had een bijzonder groot ontzag voor de geschiedenis van het boek, ${ }^{12}$ in het bijzonder natuurlijk het neogotische boek. Maar toch voelden de broeders van KOLV zich niet geroepen om naast de opleiding reclameontwerp ook een opleiding boekverzorging te installeren. Waarom is niet helemaal duidelijk. Het is best mogelijk dat de school er eenvoudigweg de middelen niet voor had (te weinig drukpersen bijvoorbeeld) of de bevoegdheid om een meesteropleiding voor drukkers te organiseren. De Kunstdrukschool werd enkel als avondschool gesubsidieerd, maar met veel goodwill en onbetaalde overuren slaagde de school er in een volledig gevuld dagprogramma tot zes uur 's avonds aan te bieden. Hoe dan ook, in het curriculum van de school speelde het boek de tweede viool. Boekverzorging als dusdanig werd niet onderwezen, studenten konden zich hooguit bekwamen in het boekbinden. ${ }^{13}$

De opleiding en het tijdschrift hadden dus nauwelijks aandacht voor het actuele boekontwerp, een vak dat volgens Jan Peeters - en hiermee trad hij in de voetsporen van William Morris - volledig was gedegenereerd tot een weinig uitdagende en monotone klus: 'Vanzelfsprekend hoeft men zoo'n danige ontwerper niet te wezen voor (...) boekopmaken, maar veeleer voor dit slag werken, waarin nieuwe uitzichten telkens weer welkom zijn: handels-, reclame- en feestdrukwerken. ${ }^{14}$ De Kunstdrukschool en Grafiek trokken dus resoluut de kaart van het reclameontwerp, een nieuwe discipline die nauwelijks een verleden had, en in die zin stuurden ze dus aan op een moderne eigentijdse vormentaal. Voeg daarbij het gegeven dat Grafiek een periodiek was van alumni van een school die zich gaandeweg verwijderde van het centrale gezag van Sint-Lucas, en het wordt duidelijk waarom het tijdschrift een podium werd voor de 'modernisten' binnen de Sint-Lucasgemeenschap. Uit de expliciete keuze voor het reclamedrukwerk en de ontwikkeling van een nieuwe adequate vormentaal voor deze nieuwe discipline, blijkt bovendien dat zowel het blad als de opleiding de weg voorbereidde voor de nieuwe professie van de grafische vormgever.

\section{DE KOLV-STIIL: NAAR HET VOORBEELD VAN DE NEDERLANDSE EN DUITSE GRAFISCHE VORMGEVING}

Karakteristiek voor Grafiek zijn de katernen (in een andere papiersoort) met vele naamkaarten, briefhoofden, vouwbladen, reclamekaarten, uitnodigingen en advertenties. Het drukwerk werd toegestuurd door leden van de oud-leerlingenbond (KOLVO) en moest de lezers een goed voorbeeld voorhouden van modern grafische vormgeving. ${ }^{15}$ De overvloed van kwaliteitsvol eigentijds drukwerk verleende het tijdschrift een luxueus cachet, te vergelijken met dat van het Franse Arts et métiers graphiques. In België wist het jonge blad zich er mee te onderscheiden van andere drukkersbladen, zoals het Brusselse La chronique graphique. ${ }^{16}$

Omdat er een groot aantal ontwerpen op deze manier bewaard bleef, is het mogelijk om een stijl - die ik in dit artikel de KOLV-stijl noem, naar de Kunstdrukschool Onze-Lieve-Vrouw - te beschrijven.

De ontwerpen in Grafiek hebben met elkaar gemeen dat ze voornamelijk typografisch van aard zijn met veel wit. Elk ontwerp in de KOLV-stijl vertrekt vanuit de typografie, eventueel in combinatie met een lijntekening of met een puzzelstukje samengesteld uit geometrische drukkersornamenten. De vlakverdeling is doorgaans asymmetrisch en wordt soms ook geaccentueerd - gestut of onderlijnd - met lijnen en balken. Er is ook plaats voor

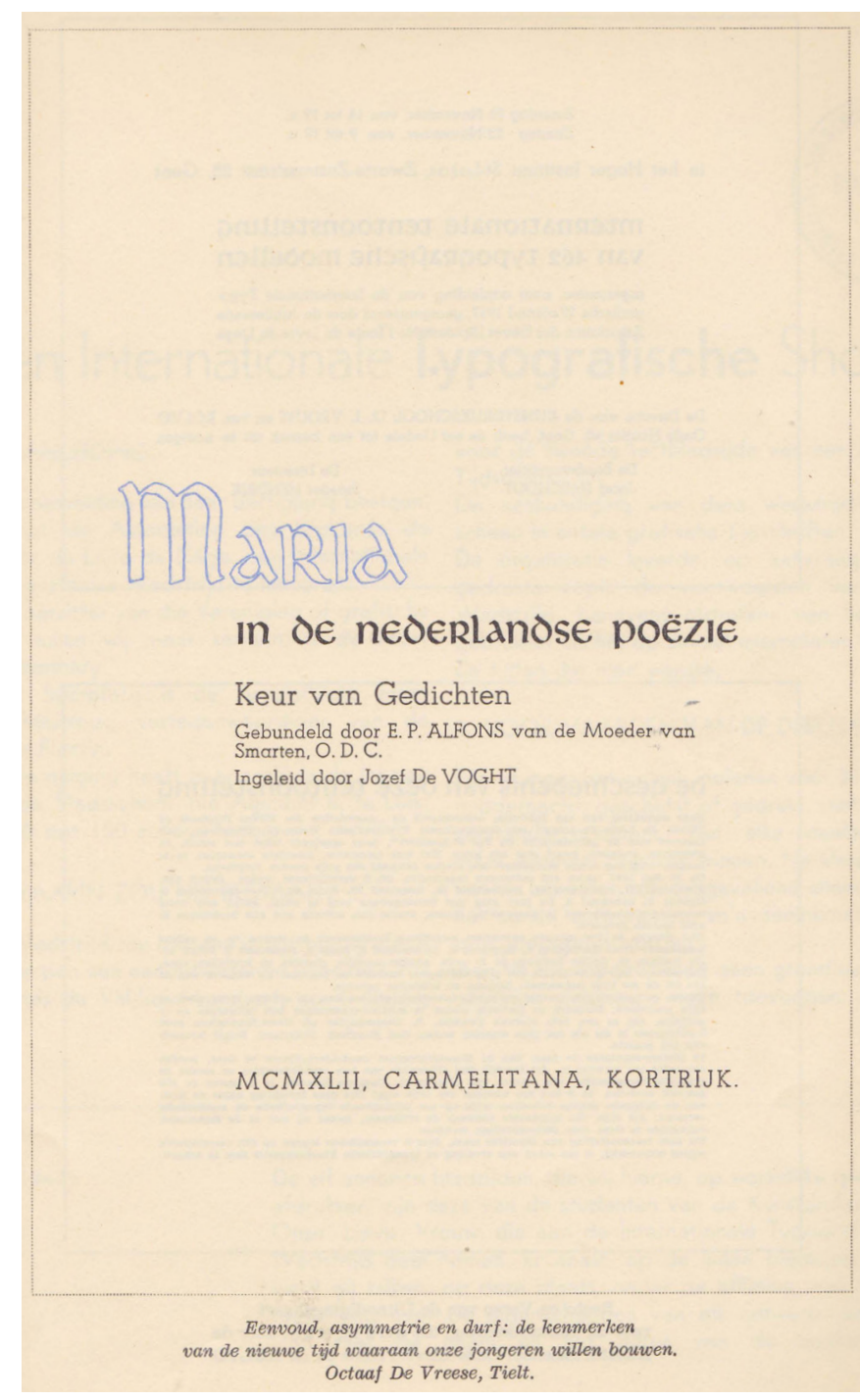

Een selectie uit de uit de vele drukmodellen (zie ook volgende bladzijde). 
foto's, al dan niet losgemaakt van de achtergrond, maar die komen minder frequent voor misschien omwille van de kostprijs.

Opmerkelijk is de voorkeur van de redactie van Grafiek voor relatief klein drukwerk zoals briefpapier, naamkaartjes, uitnodigingen, reclamekaarten, advertenties. In zekere zin was dit een logisch gevolg van hun keuze om zoveel mogelijk met zetmateriaal te werken, wat technisch gezien in die tijd veel moeilijker was voor grote formaten. Misschien was de redactie ook van mening dat het ontwerp van een affiche te veel op het terrein kwam van de vrije kunsten. Hoe dan ook, vergeleken met het kleine efemere drukwerk, kwam de affiche in Grafiek veel minder aan bod.

De KOLV-stijl voelt Nederlands en Duits aan en wijst minder in de richting van Frankrijk, wat voor België toch ook een invloedrijke buurman was wat de geschiedenis van de typografie betreft. Het Franse moderne grafische ontwerp zag er heel anders uit. Designhistoricus Philip Meggs classificeerde het als 'post-cubist pictorial modernism', een picturale en kleurrijke grafische stijl van voornamelijk affiches met een vereenvoudigde vormentaal en een kloeke

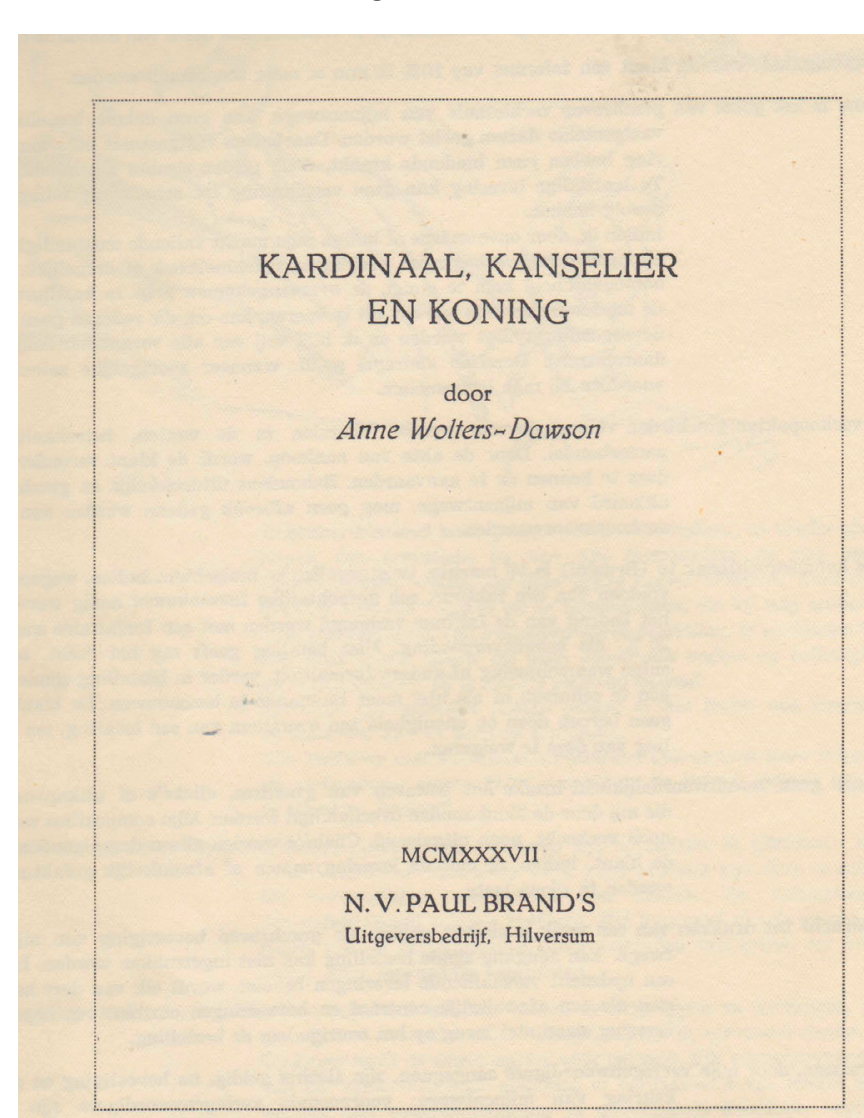

belettering. ${ }^{17}$ In Frankrijk leek het moderne grafische ontwerp eerder gegrondvest op de schilderkunst dan op de typografie.

In de eerste helft van de twintigste eeuw bevond grafisch België zich geografisch tussen twee belangrijke vernieuwers: Frankrijk in het zuiden en Nederland en Duitsland in het noorden en oosten. De vaststelling dat de KOLV-stijl zo weinig met de Franse stijl te maken heeft, is op zich opmerkelijk aangezien de Belgische drukkerijen en letteruitgeverijen traditioneel op Frankrijk gericht waren. ${ }^{18}$ Maar de broeders van de Kunstdrukschool liepen niet zo hoog op met Frankrijk. Zij waren flamingant in hart en nieren en trots dat zij de eerste drukkersopleiding konden aanbieden in de eigen Nederlandse taal. Gedreven door hun Vlaamse ontvoogdingsstrijd voelde de redactie van Grafiek een groot ontzag voor het Nederlandse en Duitse drukwerk.

In België keerde ook de grafisch vormgever Jos Léonard zijn blik naar het noorden. Zijn oeuvre vertoont grote parallellen met de KOLV-stijl. Legt men de modellen van Grafiek naast de ontwerpen van Jos Léonard uit dezelfde periode, dan vallen de stilistische gelijkenissen meteen op.

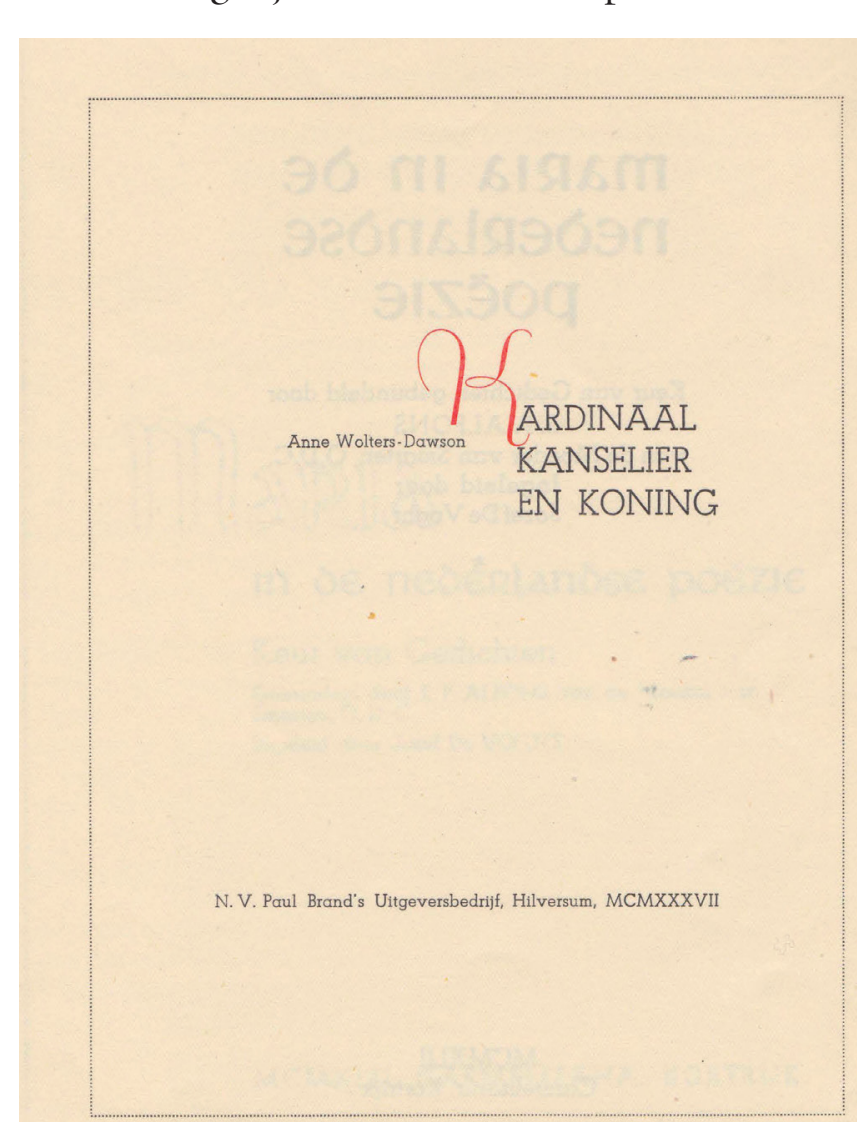




\section{ÉTABL."PLANTIN"S.A.}

BRUXELles, PARIS, AMSTERDAM, ANVERS

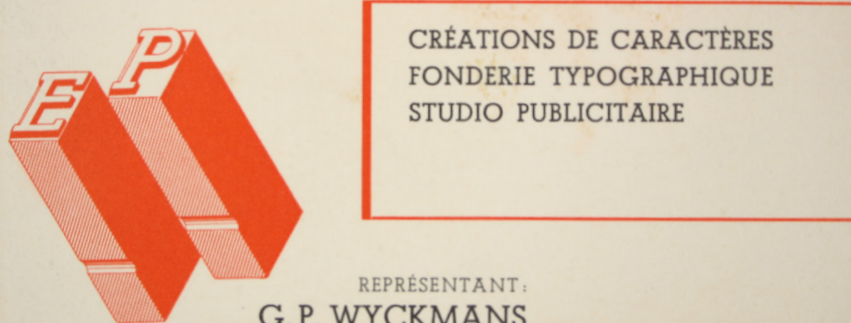

18. RUE DE LA VÉGA. PARIS XIIE

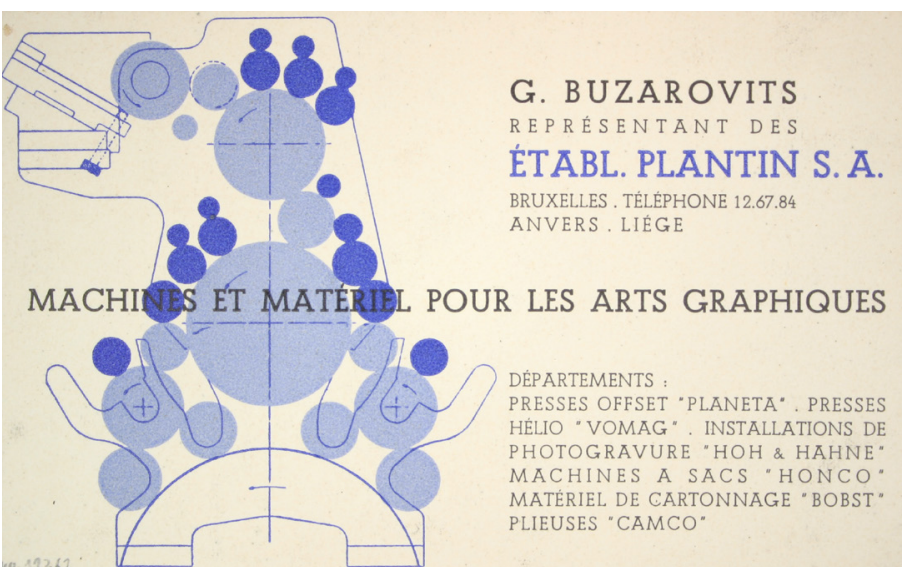

Ontwerpen van Jos Léonard voor Etablissementen Plantin.

Hoewel Léonard nooit lid is geweest van KOLVO, kunnen we er toch van uit gaan dat hij een goed contact had met de opleiding, in het bijzonder met Jan Peeters. Dat blijkt bijvoorbeeld uit Peeters' postume biografie van Léonard waaruit een grote bewondering en een oprechte vriendschap spreekt. ${ }^{19}$ De vriendschap moet wederzijds geweest zijn, aangezien het Léonards uitdrukkelijke wens was dat na zijn dood zijn vakbibliotheek aan de Kunstdrukschool zou geschonken worden. ${ }^{20}$

Waarschijnlijk maakte Grafiek voor het eerst kennis met Jos Léonard via de Brusselse letteruitgeverij Plantin. Grafiek had veel aandacht en respect voor 'Het informeerde zijn lezers wanneer Plantin een nieuw lettertype of een nieuwe machine op de markt bracht zoals automatische zetmachines, degelpersen, rotatiepersen, proefdrukpersen of inlegapparaten. De directie van Plantin toonde op haar beurt interesse voor het tijdschrift Grafiek. De publicatie van het eerste nummer was niet aan haar aandacht ontsnapt, zo blijkt uit de publicatie van Plantins lezersbrief: 'Wij weten uw werk en niet het minste uw durf te waarderen. Bij de modellen, die aan dit nummer zijn toegevoegd, zijn er vele die ons bijzonder bevallen. De mise-en-page is verder goed, de tekst goed gezet, maar de druk kon beter zijn. ${ }^{22}$ De toon van Plantin is collegiaal, maar ook een tikkeltje betuttelend. ${ }^{23}$
In de jaren dertig en veertig was het contact met het bedrijf Plantin zo nauw geworden dat het wel leek in de KOLVO-familie opgenomen te zijn. Een medewerker van Plantin beschouwde Grafiek als 'één van ons'. Tenminste, zo lijkt het wel wanneer Grafiek een paginavol eresaluut publiceerde voor de oudste werkman die Plantin na 27 jaar dienst verliet. ${ }^{24}$

Ook Léonard werkte voor de firma Plantin. Sinds 1932 stond hij er aan het hoofd van hun Studio Plantin en bestond zijn opdracht eruit om de reclame te ontwerpen én aan voorlichting te doen. Daarom organiseerde hij voordrachten en tentoonstellingen. Maar wat belangrijker is: hij ontwierp talloze drukmodellen. Die moesten tonen aan de drukkers in België hoe ze op een eigentijdse manier konden ontwerpen met de lettertypes van Plantin. ${ }^{25}$ Het ligt voor de hand dat Léonards modellen ook Grafiek bereikten en inspireerden. ${ }^{26}$

Kortom, zowel Jos Léonard als de firma Plantin had een grote invloed op de KOLV-stijl. Geen onbelangrijk detail is dat Plantin een filiaal was van de Nederlandse Lettergieterij Amsterdam die tussen 1920 en 1960 in Nederland een monopolie had uitgebouwd. Dat monopolie was ontstaan omdat het bedrijf ook de machines distribueerde waarop enkel hun lettertypes pasten. ${ }^{27}$ Wanneer Grafiek ervoor koos om met Nederlandse lettertypes van Plantin te werken, dan veronderstelde die keuze in feite een langdurig engagement. Samen met de lettertypes en de machines werd ook een bepaald vormgevoel uit Nederland geïmporteerd, zij het dan gefilterd door Jos Léonard.

Het lijkt er dus op dat de KOLV-stijl geen geisoleerd fenomeen was maar in een ruimere context kan gesitueerd worden. Zo toonde de stijl overeenkomsten met het oeuvre van de ontwerper Jos Léonard die in de jaren dertig en veertig in België als een autoriteit gold. De KOLV-stijl is bovendien via de firma Plantin gekoppeld aan de Lettergieterij Amsterdam, een Nederlands bedrijf dat zijn stempel generatieslang drukte op de Vlaamse drukindustrie.

\section{DE VIJF ZET-FORMULES' VAN JAN PEETERS VOOR DE 'ZETTER-ONTWERPER'}

De vele ontwerpen in de KOLV-stijl - de redactie van Grafiek sprak consequent over 'modellen' werden niet gewoon gepresenteerd an de lezers, ze werden stilistisch geanalyseerd en kritisch besproken. Jan Peeters was de man die het vaakst in de pen kroop en soms op een paternalistisch toontje oordeelde wat goed was en wat slecht. Zijn oordeel was echter niet louter subjectief maar gebaseerd op een visie die hij zelf had ontwikkeld 
en in een reeks artikels stapsgewijs uiteenzette. Aangezien Peeters zijn model vaak illustreerde met ontwerpen van studenten of pas afgestudeerden, kunnen we er van uitgaan dat de reeks met 'zetformules' ook als leidraad diende voor zijn onderwijs.

Reeds vanaf het vierde nummer in 1937 konden de abonnees van Grafiek, dus ook de studenten van de Kunstdrukschool, met zijn ontwerpmethodiek kennismaken. De opleiding was intussen al ruim tien jaar oud en ontsteeg geleidelijk aan het amateurisme van weleer. De eerste academiejaren moet het er in de Parnassus niet al te professioneel aan toe zijn gegaan. Dat kon ook moeilijk anders. De broeders die er les gaven begonnen vrijwel zonder voorbereiding aan hun nieuwe functie. Gelukkig werden ze bijgestaan door een handvol vaklieden die de oude drukpersen konden bedienen en enkele leraars van de moederschool Sint-Lucas die de studenten 'smaak' moesten bijbrengen. ${ }^{28}$

Maar het resultaat was niet bevredigend, herinnerde Jan Peeters zich. Terugblikkend in 1946 noemde hij die beginjaren een 'vergissingsperiode'. Ter illustratie toonde hij een van de oudste drukwerken van de Kunstdrukschool: een briefhoofd voor de firma Buyse-De Kimpe. Het is volgens hem vakkundig gezet en gedrukt maar niet ontworpen, tenminste niet bewust.

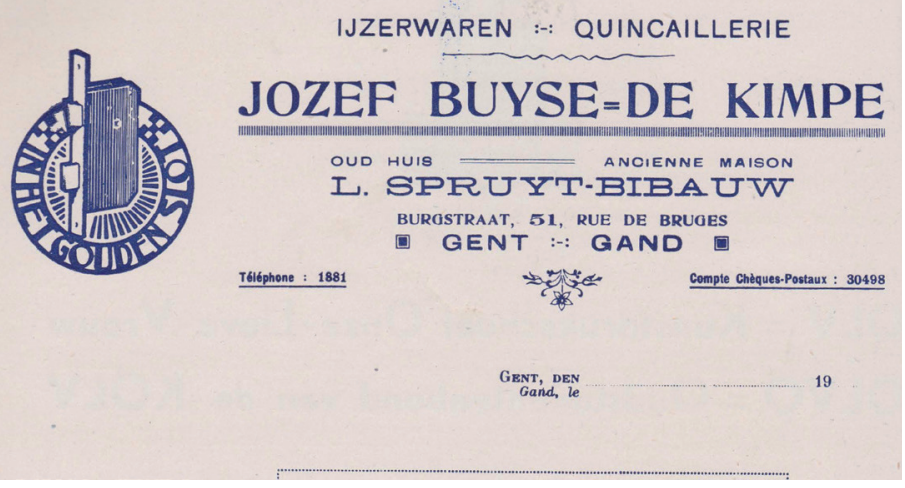

Briefhoofd voor de firma Buyse-De Kimpe in: Grafiek, no. 20 (1946).

De drukker van dienst had gewoon slaafs de oude formules gevolgd en leek zich weinig te hebben bekommerd om compositie, contrast, vlakverdeling, evenwicht en zo meer.

Peeters zag het als zijn missie om de studenten te leren wat ontwerpen was. Hij stelde namelijk vast dat het woord ontwerpen bij velen reeds verwarring teweeg brengt en in sommige drukkerijen zelfs totaal vreemd schijnt te zijn.' ${ }^{29}$ Voor Peeters was het van cruciaal belang dat de Kunstdrukschool zelfstandig zou worden en op termijn het hele curriculum zelf zou invullen. Hij deelde deze ambitie met zijn directeur, broeder Jan Berchmans Cornille, die in de loop van zijn dertien jarig leiderschap (1933-1946) steeds meer expertise van lekenleraars wist aan te trekken. Berchmans' eerste wapenfeit was de naamsverandering van de school, een symbolische stap. Het was echter nog wachten tot 1953 voordat de school volledig autonoom werd (hoewel het gebouw wel eigendom bleef van Sint-Lucas). ${ }^{30}$

Toen directeur Jan Berchmans in 1946 de fakkel doorgaf, leek Peeters de opvolger Willem van Lommel (broeder Hendrik) te willen herinneren aan deze strijd en schreef militant in het vreemde taaltje dat hem eigen was:

Eigen schoon! Adel van typografische eenvoud en bezonkenheid! Wij zullen ons 'eigen' vaandel, wars van alle andere technieken of inzichten, verder door het leven vechten, en hoog dragen! Wij, en niemand anders voor ons. Wij meenen, dat de kunstvoelende-zetter en niet de typografisch voelende kunstenaar de ideale en tevens de meest realistische ontwerper of opvoeder is..$^{31}$

Kortom, twintig jaar na de opening van de school was het voor Jan Peeters zonneklaar dat de typograaf zelf verantwoordelijk was voor de richting die het moderne grafische ontwerp in de toekomst zou uitgaan en niet de kunstenaar, zelfs al had die veel gevoel voor typografie. Hoewel hij aanvankelijk zelf een amateur was in het vak, ${ }^{32}$ beschouwde hij zichzelf als een 'kunstvoelende-zetter'. Zijn collega, Jan Dierckx (broeder Edwaard) noemde hem een 'typographe artiste'. 33

Vandaag zou Jan Peeters zichzelf grafische vormgever noemen, maar deze begripsaanduiding vond in België pas algemeen ingang na de Tweede Wereldoorlog. ${ }^{34}$ Het is interessant om te lezen hoe hij op zoek ging naar een woord dat volgens hem exact verwoordde tot welk beroep de Kunstdrukschool haar studenten opleidde. Het woord 'zetter' voldeed uiteraard niet, want dat suggereerde een louter technische benadering. Daarom probeerde hij allerlei nieuwe woordsamenstellingen uit. Zoals 'potlood-zetter'. ${ }^{35}$ Het potlood, hét attribuut van de vrije kunstenaar, was cruciaal. Met dit woord gaf Peeters te kennen dat hun typografen niet moesten onderdoen voor de kunststudenten aan Sint-Lucas:

Wij denken niet te hoogdravend te zijn wanneer wij de typografie (hierbij verwarre men niet met den vakkundigen term 'letterzetten' maar wel het ontwerpen ervan) als kunst gaan beschouwen. ${ }^{36}$

De typograaf was net zo goed een kunstenaar, daar was de Kunstdrukschool van overtuigd. Zij het wel dat deze overtuiging met enige pragmatiek gepaard ging. De school had namelijk pas overheidssteun gekregen nadat broeder Denis (Alfons Frans De 
Schepper), toenmalige directeur van Sint-Lucas, de minister kon garanderen dat het drukwerk artistiek geïnspireerd zou zijn. ${ }^{37}$

Het potlood, of het tekenen, kreeg dus veel aandacht in de opleiding. 'Gaandeweg, rijpt wel in ons de overtuiging: Ontwerpen kan! Maar dan maken wij van het potlood, na den zethaak, ons voornaamste werktuig.' ${ }^{8}$ Studenten mochten niet rechtstreeks naar de zetkast gaan om daar hun ontwerp samen te stellen maar moesten het ontwerp eerst volledig uittekenen, inclusief de letters. ${ }^{39}$ In een inspectieverslag van 1948 getuigt een zekere L.E.J. van het uitmuntende niveau waarop studenten lettertypes natekenden. Ze waren nauwelijks te onderscheiden van de gedrukte. ${ }^{40}$

Andere woordsamenstellingen die volgens Jan Peeters de lading van het nieuwe beroep konden dekken waren 'zetter-virtuoos', 'zetter-bouwmeester', 'ingenieur in het zetten' en 'zetter-ontwerper', het woord dat uiteindelijk ingang vond. ${ }^{41}$ Deze zetter-ontwerper was veel vrijer dan de klassieke drukker, maar die vrijheid bracht ook grotere verantwoordelijkheden met zich mee. Elke beslissing, elke keuze in het ontwerpproces moest hij kunnen motiveren. In tegenstelling tot de symmetrische lay-out waarbij de bladschikking al grotendeels vastligt, impliceert de keuze voor een asymmetrische compositie een grotere inbreng van de ontwerper. In dit geval zijn de schikkingsmogelijkheden legio en niet elke ontwerper kon zo veel artistieke vrijheid aan.

Daarom wilde Peeters de jonge ontwerpers een houvast geven en bedacht een systeem van 'vijf zet-formules'. ${ }^{42}$ Compact samengevat: de 'titel regelval' en de 'groepsregelval' aren gecentreerde symmetrische bladschikkingen overgeleverd uit de geschiedenis van het boekontwerp. Wanneer het om een 'voorname' boodschap ging, was de keuze voor een van deze bouwformules gerechtvaardigd. Bij elke formule hoorde ook een 'eigen lettervoorkeur'. Voor de 'titelregelval' was dat Bodoni (modern face), voor de groepsregelval een 'sierlijke klassieke boekletter' van na 1500 , een 'old face' met andere woorden.

Opmerkelijk is dat zelfs de meest klassieke modellen met een symmetrische opmaak er toch modern uitzagen. Dat komt wellicht door het schaarse gebruik van traditionele drukkersornamenten. Bovendien gebruikte Grafiek steevast nieuwe lettertypes, of het nu ging om een modern schreefloos ontwerp, zoals Nobel, of om een revival zoals Egmont of Grotius. Men zal ook nooit een Art Nouveau lettertype aantreffen, tenzij in de 'slechte' voorbeelden. Een Art Nouveau letter moet als een vloek geklonken hebben in een omgeving die nog steeds doordrongen was van neogotiek. ${ }^{43}$
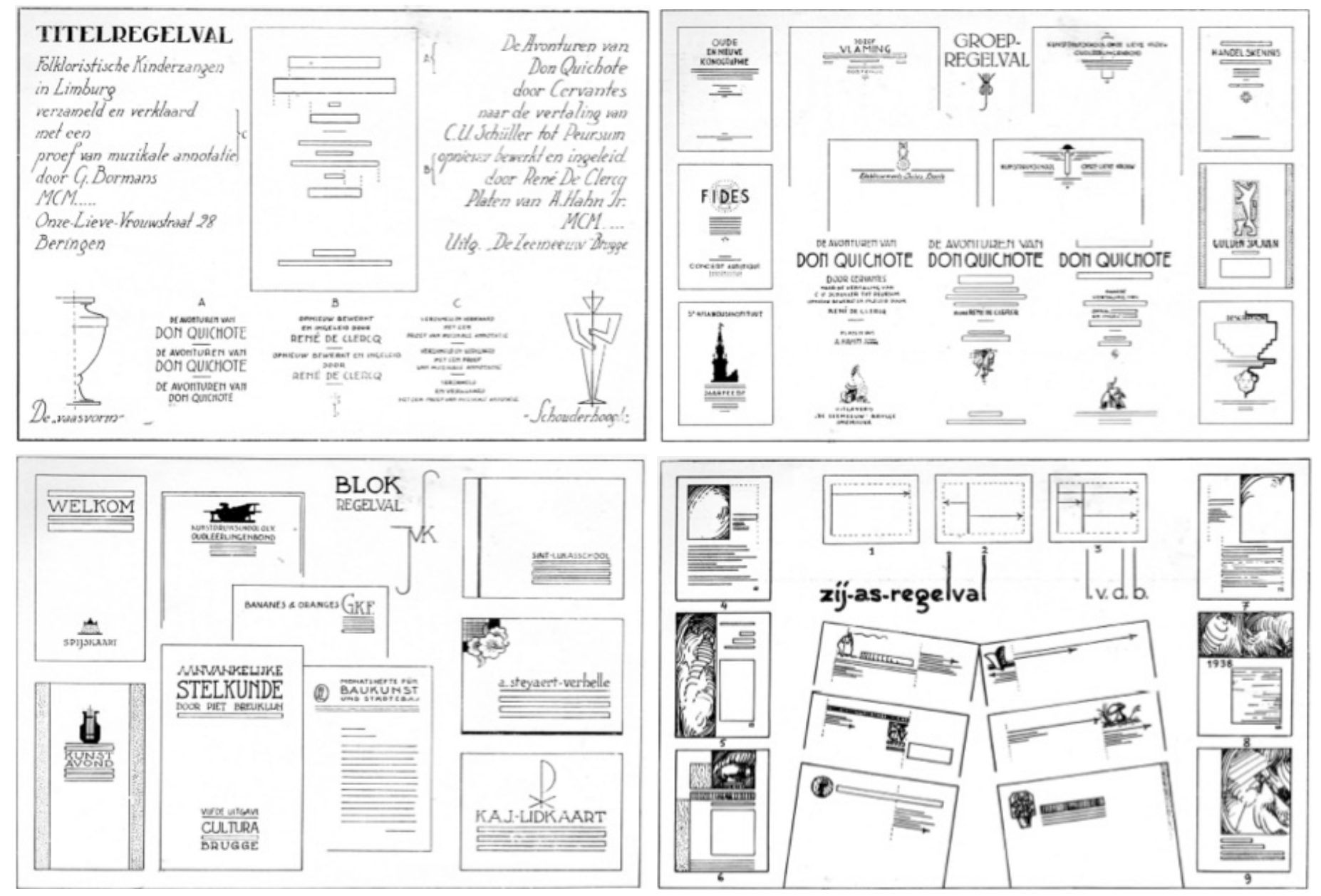

Jan Peeters (broeder Zephirijn), “Zet-formules”, Grafiek, no. 8 (1939). 


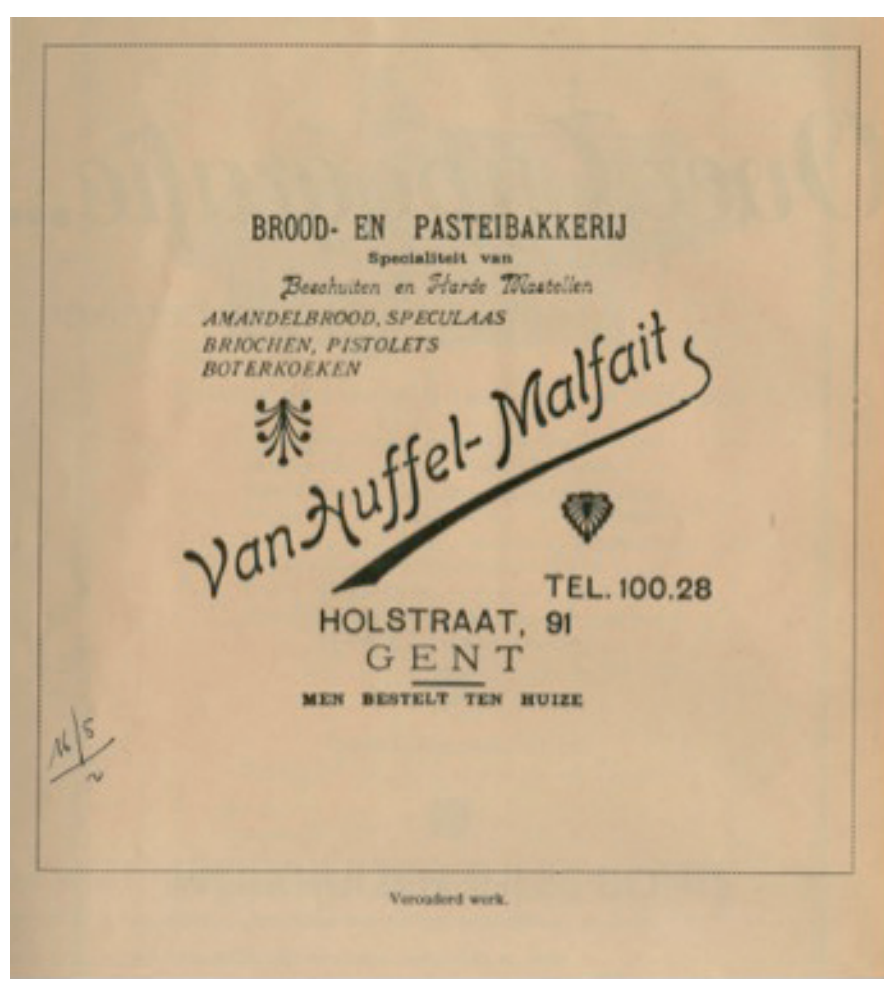

'Verouderd werk' in: Grafiek, no. 16 (1943).

De grote vernieuwing was de 'zij-as regelval', de formule waarbij de as, of assen, waarop het ontwerp zich oriënteert, om het even waar op het blad kunnen staan, behalve centraal. De tekst, door de assen gelinieerd, kon in blokregelval staan of net zo goed in een vrije regelval (links of rechts gelijnd). Een beetje verwarrend misschien is de aparte categorie 'blokregelval'. Bij deze formule maakte het blijkbaar niet uit waar de as zich bevond. De laatste formule tenslotte lijkt al helemaal te bevestigen dat Peeters het zelf moeilijk had om zich te oriënteren in het moderne grafische ontwerp: met de 'fantasieregelval' kon de ontwerper zo een beetje alle kanten op.

De 'zij-as regelval' kreeg de meeste aandacht. Het was de formule bij uitstek waarmee de ontwerper kon 'overtuigen, verbluffen, warm maken, den klant begoochelen en hem op het gemoed pakken.' Kortom, het was de formule van het reclameontwerp. Deze formule, met zijn eindeloze variaties, was het ideale instrument voor de ontwerper om de vele reclameopdrachten in een snel veranderende maatschappij te lijf te kunnen. Jan Peeters, vermoedelijk opgeleid als architect, ${ }^{44} \mathrm{zag}$ bovendien een parallel tussen de 'zij-as regelval' en de moderne bouwkunst:

omdat het terrein van het papier ditmaal planmatig wordt ingedeeld en het zetsel tegen uitgesproken constructielijnen aanleunt; daardoor ontstaan omschreven ruimten die voor het uitzicht zooveel belang hebben als de teksten zelf, (...) Het belang van de ruimte, van het vlak- ke, van het ledige, vinden wij trouwens terug als algemeen kenmerk van het moderne concept, in de bouwkunst, in het meubel, in de houtsnee, in de typographie. ${ }^{45}$

Ook deze formule wilde Peeters in een juiste historische context situeren, al was die nog zo pril. Men kan het een broeder met een neogotische achtergrond moeilijk kwalijk nemen dat hij geen radicale breuk forceerde met het verleden. Hij wist heel goed dat de oorsprong van het moderne grafische ontwerp in Centraal-Europa lag. Zo ook broeder Denis, die om de stichting van de Kunstdrukschool voor te bereiden en zich in de materie in te werken, een studiereis naar Duitsland ondernam waar hij de kunstdrukcentra van Keulen, Mainz en Frankfurt bezocht. ${ }^{46}$

Net als de opleiding wees het tijdschrift Grafiek de traditie ook niet radicaal af, zoals de modernisten van de jaren twintig aan bijvoorbeeld het Bauhaus. Grafiek trachtte steeds het moderne te begrijpen vanuit de kennis van het verleden en streefde naar een compromis. Dit kan hun grote en langdurige enthousiasme verklaren voor het lettertype Libra (Sjoerd de Roos, Lettergieterij Amsterdam, 1938), een revival van het vroegmiddeleeuwse unciaalschrift. Het unciaalschrift is een overgangsvorm in de eeuwenlange evolutie van majuskel naar minuskel. Ook Libra was bij gevolg noch kapitaal noch onderkast. Daardoor kon het lettertype, hoe traditioneel het er ook mocht uitzien, inspelen op het modernistische discours van het Bauhaus dat afzag van het onderscheid in de typografie tussen onderkasten en kapitalen. ${ }^{77}$ De Kunstdrukschool omarmde dit lettertype meteen. Het werd volop gebruikt, ongeacht de zet-formule. Jozef Imschoot, drukker en oud-leerling van de Kunstdrukschool, gebruikte het lettertype zelfs zo vaak dat het hem de bijnaam 'Libra-drukker' opleverde. ${ }^{48}$

Op het eerste gezicht lijken de 'vijf zet-formules' in tegenspraak met de vrijheid die het vak van de reclameontwerper aanvankelijk zo aantrekkelijk maakte. De ontwerper had zich nog maar net bevrijd van een ouderwets keurslijf en leek nu alweer gebonden aan regels die het tijdschrift voorstelde als wetmatigheden, soms op het dogmatische af. Sommige lettercombinaties konden volgens Peeters absoluut niet door de beugel en eveneens meende hij dat de zij-as regelval niet met om het even welk lettertype gecombineerd kon worden. Een modern ontwerp gezet in oude lettertypes was al even 'belachelijk als een neger met een hoge hoed'. ${ }^{49}$ Wie de opvattingen van Peeters echter vergelijkt met de vele 'modellen' in Grafiek, kan vaststellen dat lang niet al het voorbeelddrukwerk zich aan de gead- 
viseerd letterkeuzes hielden. De zet-formules van Peeters, hoe streng ze ook mogen klinken, waren blijkbaar voor interpretatie vatbaar.

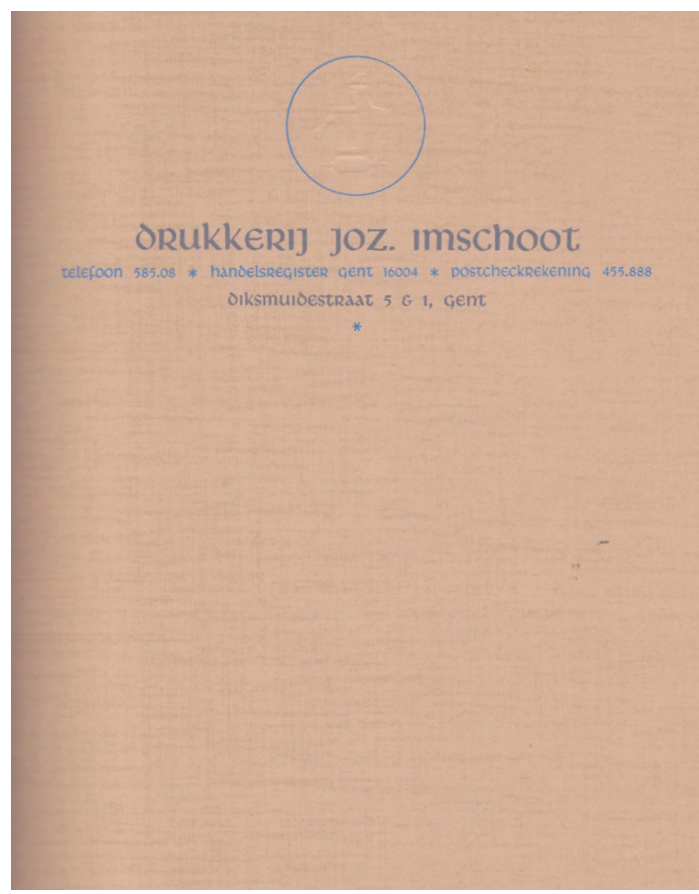

Briefpapier drukk J. Imschoot.

Ontwerp Jozef Imschoot.

Bovendien, besefte Jan Peeters, lag het woord 'formule' een beetje gevoelig. Immers bediende de ouderwetse drukker zich ook niet van een set formules die door de jaren heen steeds verder werden uitgehold? Daarom benadrukte Peeters steeds dat de ontwerper vrij was en dat hij vooral zelf, ontwerp na ontwerp, op zoek moest gaan naar een evenwichtige bladvulling met accenten en contrasten die de blik van de lezer begeleiden. Peeters kon wel een richtsnoer geven, maar de kwaliteit van het ontwerp hing uiteindelijk toch voor een deel af van de smaak en het talent van de ontwerper.

\section{MODERN MAAR NIET MODERNISTISCH}

Ontwerphistorici zijn het erover eens dat het bijzonder moeilijk is, zo niet onmogelijk, om het modernistische ontwerp in detail te definiëren. Het modernisme is immers meer dan de naam van een stijl uit de twintigste eeuw, het was ook een levenshouding en een filosofie. De kunstenaars die de modernistische denkwijze uitdroegen, vormden geen homogene groep. Het was een disparate verzameling van individuen, scholen en groeperingen, wier motivaties niet altijd verenigbaar waren en soms zelfs tegenstrijdig klonken. In 1936 kon de Engelse architectuurhistoricus Nikolaus Pevsner nog de indruk wekken dat het modernisme een coherent verhaal was, ${ }^{50}$ zijn geschiedschrijving was onvermijdelijk een selectieve constructie van het verleden.
Toch wagen sommige auteurs zich aan een opsomming van gemeenschappelijke standpunten en overtuigingen van de modernistische grafische ontwerpers. Christopher Wilk deed een verdienstelijke poging en noteerde naar aanleiding van de tentoonstelling 'Modernism. Designing a New World' (2006) de volgende punten: de uitbundige afwijzing van traditie en geschiedenis; het utopisch verlangen om een betere wereld te creëren; de wil om de wereld opnieuw uit te vinden vanuit een tabula rasa; een bijna messiaans geloof in de kracht en het potentieel van de machine en de industriële technologie; een verwerping van het toegepaste ornament en decoratie; de omarming van de abstractie en tot slot het geloof in de eenheid van alle kunsten. Verder schrijft Wilk dat al deze genoemde principes gepaard gingen met sociale en politieke overtuigingen die voornamelijk links georiënteerd waren..$^{1}$

Vergeleken met de punten van Wilk is de KOLV-stijl niet modernistisch te noemen. Het wees wel radicaal drukkersornamenten en andere overbodige 'opsmuk' af, maar keerde veel minder drastisch het verleden de rug toe. Op typografisch vlak bijvoorbeeld werd voluit gekozen voor nieuwe letterontwerpen, maar dat hoefden niet tegen wil en dank schreefloze lettertypes te zijn. De KOLVstijl maakte evenzeer gebruik van moderne revivals.

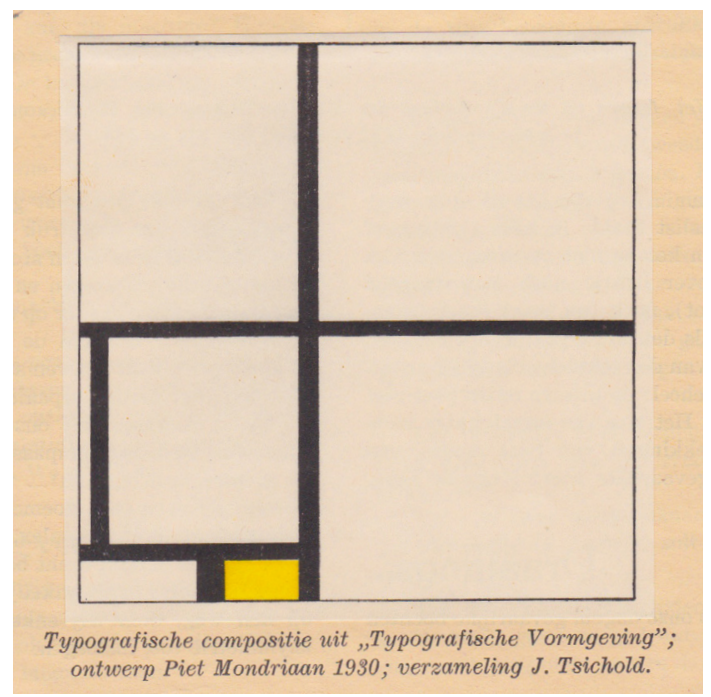

"Typografische Compositie" van Piet Mondriaan Grafiek, no. 18 (1945).

Ook Wilks aandachtspunt dat de modernistische grafische ontwerper de abstractie omarmde, is niet evident. Een abstracte compositie van Piet Mondriaan uit 1930 bijvoorbeeld werd in Grafiek 18 (1945) geridiculiseerd. Jan Peeters vond het schilderij van Mondriaan ronduit bespottelijk..$^{2}$ Verder was het enthousiasme voor de technologische vooruitgang niet grenzeloos en van een modernistisch messiaans geloof in de machine was zeker geen sprake. De broeders geloofden in de eerste plaats in God. 
Onder die grafische compositie stond een kleurig papiertje geplakt, met daarop de volgende N. B.: Ingevolge een betreurenswaardig misverstand, is de afbeelding op blz. 80 , van M..., $90^{\circ}$ gedraaid; het beeld dient zoo gezien te worden, dat het gele vlak zich aan den rechter kant bevindt."

Wij drukken het over zooals het stond, niet zooals het moest staan.

Beproef het nu eens... en draai Grafiek zoodanig dat het gele vlak zich aan Uw rechterkant komt stellen...

Ziet gij nu wat het is, wat die ontwerper bedoelde?...

Neen!?... Zie nog eens goed.

Nog niet?

$\mathrm{Nu}$, ik ook niet!...

Niet alles dus, wat in ons modern tijdperk rijpt, mag goede vrucht heeten.

Tekstfragment uit: Peeters, "Niet twijfelen! De baan zwenkt, rechtdoor razen is zelfmoord" Grafiek, no. 18 (1945).

Toch is de KOLV-stijl ondenkbaar zonder de modernisten en hun typografische experimenten. Tijdens het interbellum sijpelden hun nieuwe inzichten overal in Europa door in de vaktijdschriften, die ook aan de Kunstdrukschool in Gent volop werden gelezen. In zijn memoires noemt broeder Dierckx onder andere het Duitse tijdschrift Deutscher Drucker. En inderdaad, wie er de bibliotheekcatalogus van de Kunstdrukschool op naslaat (vandaag is dat de mediatheek van het departement Grafische Bedrijven van de Artevelde Hogeschool in Gent), zal er enkele vroege jaargangen van dit tijdschrift aantreffen. Het oudste nummer dateert al van 1925 - ouder dan de school zelf -, het is mogelijk dat broeder Denis het heeft meegenomen van zijn prospectiereis naar Duitsland. ${ }^{3}$ Het is vermoedelijk ook via Deutscher Drucker dat ontwerpers van de Kunstdrukschool in 1932 kennis maakten met Jan Tschichold. ${ }^{4}$

Men kan zonder overdrijving stellen dat Tschichold dé grote verspreider is geweest van het modernistische grafisch ontwerp in de drukkerswereld. Als klassiek gevormde typograaf schrok hij aanvankelijk van het onorthodoxe experimentele drukwerk dat hij op de legendarische Bauhaustentoonstelling van 1923 had gezien. Eens hij de kwaliteit ervan inzag, wierp hij zich op als de meest vurige verdediger van wat hij 'die neue Typographie' noemde. Het werd zijn missie om zijn inzichten in de modernistische ontwerpstrategieën te delen met zoveel mogelijk drukkers. Een belangrijk instrument voor zijn kruistocht was het netwerk van drukkersweekbladen dat zich uitstrekte over de hele westerse wereld. Daarnaast publiceerde Tschichold ook enkele handboeken. Het eerste
Die neue Typographie in 1928 , dat in een mum van tijd uitgroeide tot de bijbel van het modernistisch grafische vormgeving. 55

Vermoedelijk bereikte Die neue Typographie nooit de redactie van Grafiek, door het grote succes in Duitsland was het immers al snel uitverkocht. ${ }^{56}$ Een boek dat ongetwijfeld wel een grote impact heeft gehad op Grafiek was Typografische vormgeving (1938), de Nederlandse vertaling van Jan Tschicholds Typographische Gestaltung. ${ }^{57}$ Tschichold is in dit boek minder radicaal dan in Die neue Typographie, ook op politiek vlak. ${ }^{8}$ Tschichold, die in 1933 uit NaziDuitsland naar Zwitserland emigreerde, nam gaandeweg afstand van zijn radicale principes uit Die neue Typographie en keerde terug tot een meer traditioneel standpunt inzake typografie en zijn politieke stellingname. ${ }^{59}$

In Typografische Vormgeving onderschreef Tschichold nog steeds de gedachte dat het asymmetrische ontwerp beter past bij de moderne behoeften en hij bekritiseerde onverminderd de oude typografie met zijn ornamentele centrale as. Hij nuanceerde echter zijn kritiek op de centrale as regelval. Ook verwees hij meer naar de geschiedenis van de typografie $^{60}$ en pleitte hij niet meer exclusief voor een schreefloze typografie. De verbreding van zijn typografisch palet komt bijvoorbeeld tot uiting in het ontwerp van Typografische vormgeving zelf, dat moeiteloos een modernistische schreefloze met een negentiende-eeuws aandoende Didone en een script (een lettertype dat met de spitse pen lijkt te zijn gekalligrafeerd) combineert.

Deze intrigerende spanning tussen oud en nieuw is ook terug te vinden in de teksten van Jan Peeters die geïnspireerd lijken te zijn door het latere werk van Tschichold en met name diens Typografische vormgeving. Beiden beschouwen de typografie als de belangrijkste bouwsteen in het moderne grafisch ontwerp, maar roepen tevens opvallenderwijs het potlood uit tot het belangrijkste ontwerpinstrument. Want eens de typograaf het veilige axiale schema verlaten had, werd hij een moderne ontwerper die met potlood op papier op zoek ging naar een evenwichtige compositie voor de meer complexe opdrachten. Ook Peeters stoorde zich, net als Tschichold, aan de stereotype ouderwetse drukker die enkel uit was op winst: 'Toch zijn er nog altijd bedrijfsleiders, die het maken van schetsen als tijdverlies beschouwen. ${ }^{61}$

Sommige overeenkomsten zijn subtieler. Soms klinkt de stem van Tschichold door in specifieke woordkeuzes van Peeters. Bijvoorbeeld wanneer hij het heeft over 'lettermengelingen' (en niet over lettercombinaties), dan lijkt het alsof hij zich voor deze vreemde woordkeuze heeft laten inspireren door 
Typografische vormgeving. ${ }^{62}$ Charles Nypels, de vertaler van dienst, vertaalde namelijk Tschicholds 'mischen' (van lettertypes) met 'mengen'.63

Alhoewel Peeters veel aan Jan Tschichold heeft ontleend, schreef hij aanvankelijk niet in positieve zin over Typografische vormgeving. In 1940 noemde hij het boek 'hopeloos' en makkte er verder geen woorden aan vuil. ${ }^{64} \mathrm{Na}$ de oorlog echter, herpakte hij zich en noemde de publicatie een 'baanbrekend en richtingsgetrouw werk'. Hij bleef echter moeite hebben met dit boek dat hem duidelijk erg fascineerde. Iets weerhield zijn enthousiasme. In zijn bespreking, met de veelzeggende titel "De baan zwenkt, rechtdoor razen is zelfmoord", nam hij een ontwerp van Tschichold voor een huwelijksaankondiging (gepubliceerd in Typografische Vormgeving) onder vuur.

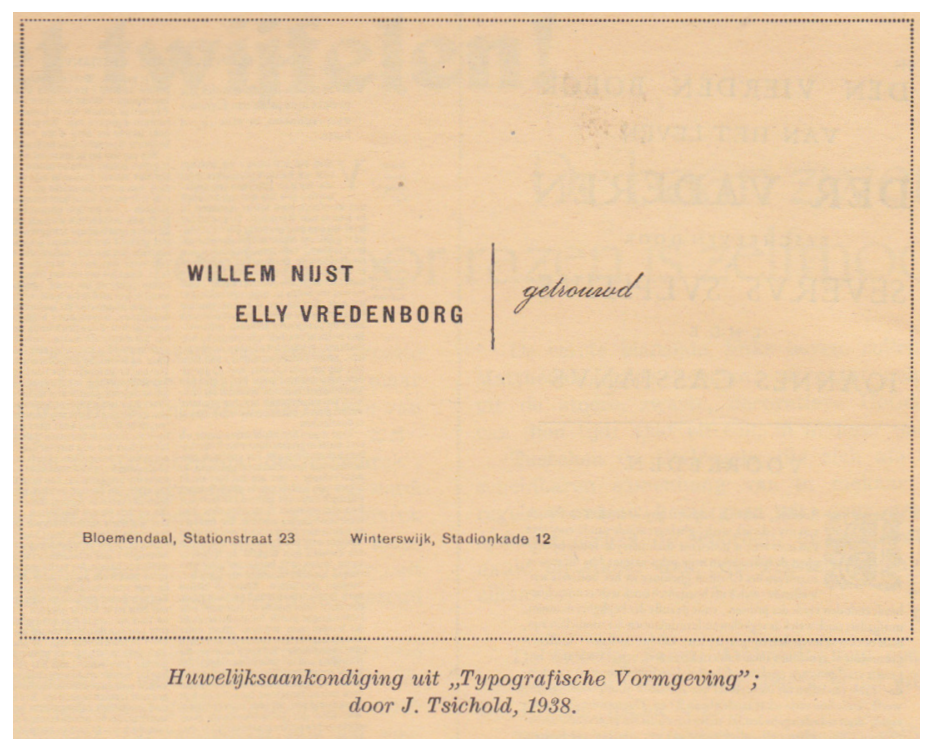

Bladzijde met reproductie van een huwelijksaankondiging door Jan Tschichold in: Jan Peeters (broeder Zephirijn), "Niet twijfelen! De baan zwenkt, rechtdoor razen is zelfmoord", Grafiek, no. 18 (1945).

Het ontwerp was volgens Peeters 'onaanvaardbaar', het was 'stof, door de geweldige snelheid aan den bocht van de baan opgejaagd; schuim, op de baren die ons den vloed aanbrengen.' Met andere woorden, Tschichold overdreef. Hij was een van die 'doodrijders' die het noorden was verloren en 'met de beste bedoelingen kwamen zij ons diets maken (...) dat de typografie nu zòò een uitzicht ging hebben. ${ }^{66}$ Jan Peeters, die voordien enthousiast de laatste ontwikkelingen volgde en een vernieuwer wilde zijn, had moeite met de laatste nieuwe mode van de 'Neue Sachlichkeit' die hij té nuchter vond. Hij kon deze niet meer volgen, zei hij, het was een bocht te veel. Volgens hem was Tschichold gewoon 'alles beu geworden'.

Een gedetailleerde analyse van de huwelijksaankondiging laat zien dat het een minimaal typografisch ontwerp is, teruggebracht tot de essentie, met veel aandacht voor het wit. De regelval is niet symmetrisch, ook niet asymmetrisch, maar een combinatie van de twee. Jan Peeters had het kunnen klasseren bij de 'fantasieregelval' en het 'modern en gedurfd' kunnen noemen. Had Peeters misschien problemen met de 'lettermengeling' van een schreefloze met een script? Vermoedelijk niet, omdat ook in de modellen van Grafiek deze lettercombinatie voorkomt, zij het dan niet zo frequent als in het oeuvre van Tschichold.

Blijft de vraag waarom hij dit kleine onschuldige ontwerp zo verfoeilijk vond? Waarin week deze af van de KOLV-stijl? Daarover kunnen we alleen maar speculeren, misschien vond Peeters het al te sober. Wat belangrijker is, hij zal het niet 'voornaam' hebben gevonden. De ontwerpers van Grafiek gebruiken namelijk vaak de adjectieven 'groots' of 'voornaam' om hun appreciatie uit te drukken. In dit ontwerp verheft geen enkel woord zich boven het geheel, alle grafische elementen zijn nevengeschikt aan elkaar. Dit ontwerp kent met andere woorden weinig hiërarchie. En het zal zeker door Peeters als ongepast zijn beschouwd voor de aankondiging van een huwelijk, dat per slot van rekening een belangrijk sacrament is in de katholieke kerk. De hang naar een nadrukkelijke hiërarchie in het ontwerp was kenmerkend voor het moderne grafische ontwerp van Grafiek, het hiërarchisch ordeningsprincipe was een van de kenmerken die de KOLV-stijl onderscheidde van het modernistisch grafisch ontwerp, zoals dat van Jan Tschichold. Peeters lijkt de visie en ontwerpmethode van de latere Tschichold te volgen, behalve dan de verwerping van het hiërarchisch onderscheid tussen de verschillende grafische elementen. Vanuit een ideologisch standpunt echter is de KOLV-stijl geenszins modernistisch te noemen. De moderne grafische KOLV-stijl was geen formele uitdrukking van het Marxistische modernistische gedachtegoed van Tschicholds Die neue Typographie ${ }^{67}$, zelfs niet van het meer gematigde Typographische Gestaltung ${ }^{68}$ waarin deze toon subtiel aanwezig bleef. ${ }^{69}$ De ideologische uitgangspunten van Jan Peeters lagen mijlenver van die van Jan Tschichold, ook al valt dat op het eerste gezicht niet af te lezen aan hun beider ontwerpstijl.

\section{POLITIEK-IDEOLOGISCHE STRIJD OM DE TYPOGRAFIE}

Grafiek was een katholiek twintigste-eeuws Belgisch tijdschrift, en het ligt niet meteen in de lijn van de verwachting dat die de sociale kwestie zo expliciet op de agenda zou zetten. In België was het imago van de socialisten immers antiklerikaal en Franstalig. Alhoewel de katholieken fel antisocialistisch waren, ${ }^{70}$ komt er in Grafiek toch een sociaal voelend 
en strijdbaar ideaal mensbeeld naar voren.

De strijd van de redactie tegen lelijk en verouderd drukwerk was lang niet hun enige strijd. Wanneer Jan Peeters voor het eerst zijn licht liet schijnen op de moderne 'zij-as regelval', besloot hij strijdlustig met de frase: 'Nieuwe tijden? Buiten twijfel; maar niemand onder ons denkt er aan dat de evolutie voltrokken of volgroeid is. ${ }^{71}$ In dit citaat had Peeters het niet meer over de strijd voor een goede typografie maar over de 'sociale, politieke, cultureele en godsdienstige strijden' die 'zullen aangegaan en gewonnen worden'..$^{2}$

Deze combattieve toon is typerend voor de eerste jaargangen van Grafiek. De redactie voerde strijd op meerdere fronten. Uiteindelijk was hun missie dezelfde als die van de Sint-Lucasscholen: via het onderwijs de samenleving evangeliseren en strijd voeren tegen de toenemende laïcisering. De oprichting van de Kunstdrukschool was in de eerste plaats een strategische zet van Sint-Lucas om het officiële netwerk van academies de pas af te snijden. In Vlaanderen had Sint-Lucas wel technische scholen op het niveau van het lager en middelbaar onderwijs voor metaal en hout, maar een technische opleiding op niveau van het hoger technisch onderwijs ontbrak. ${ }^{73}$ Deze leemte moest de Kunstdrukschool opvullen.

Broeder Denis, de eerste niet-Franstalige directeur van een Sint-Lucasschool, koppelde de Sint-Lucasstrijd aan die van de Vlaamse Beweging. De broeders van de Kunstdrukschool wilden de Vlaamse drukker in zijn eigen taal aanspreken en - hoewel ze zelf duidelijk niet de gewoonte hadden zich uit te drukken in de Nederlandse geschreven taal - het eerste Nederlandstalige vakblad voor drukkers verspreiden. Het tijdschrift is doorspekt met flamingantische retoriek, strijdlustige kreten en nostalgische herinneringen aan de meester-drukkers uit de Vlaamse geschiedenis. Veel teksten worden plots onderbroken met korte zinsneden die de troepen toespreken, zoals 'komaan jongens, vooruit!' of 'Grafiek staat paraat, slagvaardig tegen alle stormen.'

De liefde van Grafiek voor typografie was dus enigszins pragmatisch en kaderde in een ruimere emancipatie-ideologie, die ook in katholieke kringen opgang maakte, en resulteerde in de uitbouw van katholieke arbeidersbewegingen. Grafiek wilde in eerste instantie de harten van de Vlaamse grafische vormgevers (drukkers en zetters) veroveren en beloofde hen te beschermen tegen uitbuiting. Deze belofte geloofde Grafiek waar te kunnen maken door middel van een brede culturele vorming en het doorgeven van gespecialiseerde vakkennis, zowel op technisch, stilistisch als boekhoudkun- dig gebied. Het tijdschrift wilde zijn leden mondig en weerbaar maken en stelde daarom bijvoorbeeld een nieuw loonbarema samen dat vertrok vanuit de 'werkelijke sociale waarde' van elke specifieke functie in een drukkerij. ${ }^{74}$ Zo zouden de vormgevers, die over het algemeen technisch hoog geschoold en goed geïnformeerd waren en over een goede smaak beschikten, minder snel het risico lopen een loonslaaf te worden bij een drukkerspatroon. Dat was Jozef Van Kerschaever, de voorzitter van Grafiek, blijkbaar overkomen nadat hij was afgestudeerd aan de Kunstdrukschool. De teleurstelling die hij en enkele andere oud-studenten opliepen, was naar eigen zeggen de reden om het 'collectief Grafiek' te lanceren:

Wij voelden dat ons leven niet zou bestaan in te slaven, maar om te scheppen. (...) Wij vereenigen ons op corporatieve basis, omdat wij de juiste verhouding tusschen werkgever en werknemer wenschen. De werkgevers hebben er immers allen baat bij dat hun gezellen zich thuis voelen in hun werkplaatsen dat ook zij liefde voor hun vak hebben en begrepen worden. De gezellen en alle werknemers hebben er genoeg van als minderwaardigen beschouwd te worden. En met reden. ${ }^{75}$

Grafiek zet hiermee expliciet de positie van de typografische vormgever - de Vlaamse weliswaar - op de agenda en draagt hiermee bij aan de professionalisering van de beroepsgroep. Deze werd weliswaar, geheel binnen de corporatistische katholieke ideologie, voorgesteld als een bewuste proletariër, intellectueel en arbeider tegelijk. Een ideaalbeeld dat ook door Sint-Lucas werd gekoesterd. Kortom, de geschiedenis van de Kunstdrukschool en het blad Grafiek kadert in een ruimere politiek-ideologische geschiedenis van de emancipatie van het vak van grafisch vormgever. De studie van de eerste jaargangen van Grafiek geeft een inkijk in hoe een katholieke fractie in Gent kosten noch moeite spaarde om de arbeiders van een nieuwe beroepsgroep aan zich te binden en niet uit handen te geven aan de socialisten, die in Gent steeds meer terrein wonnen.

\section{HET IDEAAL VAN DE PROFESSIONELE GRAFISCHE ONTWERPER ALS VIRTUOZE AMBACHTSMAN}

Tijdens de jaren dertig en veertig waren er in Europa twee tegengestelde krachten voelbaar in de grafische vormgeving: het opkomend nationalisme en tegelijk een toenemende internationalisering qua vormentaal. Deze spanning is, zoals hierboven 
is uiteengezet, ook terug te vinden in het tijdschrift Grafiek. In nogal wat artikels komt, al dan niet expliciet, de Vlaamse Beweging aan bod. Een politiek-ideologisch programma dat echter weinig impact leek te hebben op de gepropageerde vormentaal. Anders gesteld: de KOLV-stijl ambieerde niet de grafische formele uitdrukking te zijn van een groep Vlaamsgezinde katholieken. Integendeel, de stijl streefde ernaar, zeker na de Tweede Wereldoorlog, om aansluiting te vinden bij de moderne, neutrale internationale eenheidsstijl in het drukwerk.

De principes van de Nieuwe Typografie leven na de Tweede Wereldoorlog verder in een stijl die in de Engelstalige literatuur wordt aangeduid als 'commercial modern', 'commercial printing' of 'International Style'. ${ }^{76}$ Christopher Wilk stelt dat de International Style nog steeds uitgaat van abstracte geometrie en gebruik maakt van industriële vormen en materialen, maar heeft afgezien van de oorspronkelijke sociale en politieke overtuigingen van het modernisme. ${ }^{77}$ Met de International Style is de discipline van de grafische vormgeving haar kinderschoenen ontgroeid en professioneel geworden. Internationaal groeide de consensus over wat kwaliteitscriteria voor de grafische vormgeving zijn. Deze criteria voor smaak en stijl waren niet louter subjectief meer, maar werden objectief in regels en wetmatigheden vastgelegd. Een goed ontwerp hield zich aan voorschriften en standaarden, en het was enkel aan enkele grote talenten gegeven om daar iets persoonlijks aan toe te voegen.

Ook Jan Peeters zocht aansluiting bij deze internationale eenheidsstijl. Het vierentwintigste nummer van Grafiek (1947) was volledig gewijd aan de Internationale Typografische Wedstrijd, die een uitgesproken internationaal karakter had: de deelnemers waren afkomstig uit België, Frankrijk, Nederland, Zwitserland, Engeland, Italië, Luxemburg en Canada.$^{7}$ Deze wedstrijd werd georganiseerd door oud-studenten van de École du Livre uit Luik en kan ons vertellen hoe de moderne grafische vormgeving, in het bijzonder dat van Kunstdrukschool, in België werd gerecipieerd. Jan Peeters schreef als waarnemer een verslag van deze wedstrijd voor Grafiek. 79

Uit Peeters beschrijving van de wedstrijd spreekt een grote hang naar neutraliteit en objectiviteit. De formulering van de opdracht gaf de deelnemers weinig artistieke vrijheid. De opdracht bestond uit het ontwerp voor Cristalleries du Val St-Lambert, met een aantal lijnen verplichte tekst en een foto van een kristallen vaas (de hoofdprijs). Elke deelnemer kreeg hetzelfde raster cliché toegestuurd (een foto gebruiken betekende in die tijd werken met een raster cliché en dat had uiteraard een vast formaat). ${ }^{80}$ Ook het papierformaat lag vast, kwarto raisin ${ }^{81}$ en de ontwerpen mochten slechts met twee kleurgangen gedrukt worden: 'zwart plus een kleur'. Niet alleen werd de vrijheid van de ontwerpers ingeperkt, de jury was ook streng. Zo werden verschillende (voornamelijk Zwitserse) ontwerpen geweigerd omdat de foto uit zijn kader was gehaald (in vakjargon heet dit vignetteren of detoureren) ${ }^{82}$ Er werden in totaal 462 ontwerpen ingezonden, waarvan de 30 beste een prijs kregen.

Uit Peeters tekst blijkt verder dat de jury polste hoe ver de modernisering van het grafisch ontwerp was doorgedrongen in elk land. Nederland en Zwitserland kregen, zoals te verwachten, alle lof, al was het wel een Italiaan die de eerste prijs wegkaapte. Engeland was volgens Peeters 'een bazar [sic] van uiteenlopende strekkingen; mensen, die hun traditie tot op de draad versleten hebben en zich niks thuis voelen in het moderne pak, dat ze stuk na stuk beginnen te passen. ${ }^{1{ }^{3}}$ Frankrijk speelde nauwelijks mee. Volgens Peeters kon het land moeilijk een hoog niveau bereiken omdat het nog volop zijn wonden van de Tweede Wereldoorlog aan het likken was: 'De Typografie van Frankrijk noemen we iets als een pover leventje tussen de puinhopen van verwoeste steden.' Duitsland was de grote afwezige in deze wedstrijd. Het land waar Grafiek voor de oorlog zo naar had opgekeken werd in 1947 doodgezwegen. Ook tijdens de oorlog kwam Duitsland nauwelijks in het tijdschrift aan de orde, het werd noch bejubeld noch bekritiseerd. Wat precies de houding was van de Kunstdrukschool tegenover de Duitse bezetter is nog niet onderzocht. ${ }^{{ }^{8}}$

'En België?' vroeg Peeters zich af. Deze wedstrijd bewees volgens hem dat de Belgen zich niet langer moesten schamen voor hun noorderburen. Ze hadden het er al bij al nog niet zo slecht van af gebracht. Maar dé grote verrassing kwam toch uit Vlaanderen, waar de studenten van de Kunstdrukschool blijkbaar 'de verst doorged reven moderne richting voorstonden.' Dat bleek volgens hem uit de cijfers: van de 176 Belgische inzendingen werden er zes bekroond, en van die zes laureaten waren er maar liefst vier afkomstig van de Gentse Kunstdrukschool. Nochtans hadden 'slechts' tien studenten uit het derde jaar atelier Zetkunst aan de wedstrijd deelgenomen. Hun ontwerpen werden alle tien in Grafiek op ware grootte en met een toelichting van Jan Peeters gereproduceerd. Ze lijken stuk voor stuk de ontwerpprincipes van Jan Peeters op voorbeeldige wijze te illustreren. Zijn onderwijs had met andere woorden vruchten afgeworpen. Uit deze begeleidende commentaren van Peeters blijkt dat de grafische ontwerper van de toekomst 
inderdaad geen kunstenaar is, maar in de eerste plaats een goede, op technisch én ontwerpmatig vlak geschoolde vakman. Grafisch ontwerpen als een nieuwe professie heeft zijn eigen regels en wetmatigheden, een eigen beroepscode en een eigen werkveld: reclamedrukwerk. Het ideaalbeeld van de grafische vormgever is niet dat van een geïnspireerd kunstenaarsgenie dat zijn eigen artistieke, subjectieve talenten volgt, maar dat van een getalenteerde en gedisciplineerde ambachtsman. Alhoewel de Kunstdrukschool zich in haar vernieuwingsdrang van de moederschool verwijderde, is dit ideaalbeeld van de virtuoze ambachtsman toch in overeenstemming met de katholieke ideologie van de Sint-Lucasscholen. 


\section{NOTES}

1. Een fileet of 'Engelse lijn' is een oude drukkersterm voor een lijn die in het midden dikker is dan aan de uiteinden. Een vignet, 'fleuron' in het Frans, is een klein decoratief element in het zetwerk, meestal gekopieerd naar historische voorbeelden. 'Cul-de-lampe' is de Franse term voor sluitvignet, een vignet dat aan het einde van een hoofdstuk wordt gezet, in het bijzonder wanneer een groot deel van de pagina onbedrukt blijft. Een lettrine is het Frans voor initiaal, een grote, al dan niet versierde beginletter. Huib Van Krimpen en Rob van den Elzen, Grafisch zakboek. Algemeen verklarend woordenboek van hedendaagse begrippen uit de grafische communicatie: uitgeverij, redactie, vormgeving, prepress, drukkerij en afwerking (De Bilt: Cantecleer 1995), nr. 926; nr. 1127; nr. 1458.

2. Wat de positie van België was in deze Europese geschiedenis wordt belicht in: K. Van Haute, "Grafisch ontwerp in België tijdens het interbellum" in Modernisme. Belgische abstracte kunst en Europa, red. Johan De Smet (Gent, MSK/Mercatorfonds, 2013), 187-205.

3. Herbert Spencer, Pioniers van de moderne typografie, (Amsterdam, Meulenhoff/Landshoff, 1982) [oorspr. Pioneers of Modern Typography (Londen: Lund Humphries, 1969)].

4. Robin Kinross, Modern Typography, an Essay in Critical History (Londen: Hyphen Press 1992), 49.

5. In 1932 namen enkele oud-studenten het initiatief om een coöperatieve op te richten en op het tienjarig jubilee van de school kondigden ze de start aan van hun eigen tijdschrift Grafiek. Het eerste nummer in 1936 kreeg de titel Hou Zee. Van 1937 tot 2000 verscheen het tijdschrift onder de titel Grafiek. Het is goed mogelijk dat de oud-studenten, Jozef Van Kerschaever op kop, zich hadden laten inspireren door de oud-leerlingen van de Utrechtse 'School voor Grafische vakken' die al in 1920 hun eigen vaktijdschrift De Tampon (1920-1972) lanceerden. Dit was een van de tijdschriften waarop de Kunstdrukschool in de beginjaren geabonneerd was. P. J. Dierckx, "Grafiek. De gouden jubilaris", Grafiek, no. 148 (1986): 6.

6. Bij de oprichting in 1926 werd de school Kunstdrukschool Sint-Lucas genoemd. In 1933 veranderde broeder Jan Berchmans Cornille de naam in Kunstdrukschool Onze-Lieve-Vrouw (KOLV). In 1964 werd de school herdoopt tot Hoger Instituut voor Grafisch Onderwijs (HIGRO). De campus fuseerde in 2000 en vormde samen met enkele andere Gentse Hogescholen de Arteveldehogeschool. De opleiding heet vandaag 'grafische bedrijven'.

7. Heel anders is de situatie voor het onderzoek naar de oudste opleidingen grafische vormgeving in Brussel (Hoger Instituut voor Sierkunsten Ter Kameren) en in Antwerpen (Vakschool voor Kunstambachten, een avondschool), waar naar mijn kennis geen dergelijk tijdschrift bestond. Ook deze scholen openden hun deuren in 1926 en waren, net als de opleiding in Gent, een reactie op de 'armzalige' Belgische vertegenwoordiging tijdens de Art Déco tentoonstelling in Parijs in 1925. Roger Avermaete, Herinneringen uit het kunstleven (1918-1940) van specialisten, kenners, paedagogen en andere artisten, prt. III (Brussel: Manteau, 1955) 95-160; Jaak Fontier, "Van art deco tot installatie", Vlaanderen, no. 1 (1997): 200. Het pedagogisch project van deze opleidingen is minder goed gedocumenteerd. Zo had Henry Van de Velde, de charismatische directeur van Ter Kameren, een handgeschreven cursus over 'de letter' maar hij heeft deze nooit gepubliceerd. Fernand Baudin, "Het Belgische Boek", in Anderhalve eeuw boektypografie (1818-1965) in Amerika, Engeland, Frankrijk, Duitsland, Zwitserland, Italië, België en Nederland, red. G.J. Thieme (Amsterdam: J.M. Meulenhoff, 1965), 322. Het manuscript was in het bezit van Raphaël Verwilghen (professor aan het Hoger Instituut voor Sierkunsten Ter Kameren van 1929 tot 1946) op het moment dat Fernand Baudin zijn artikel over het Belgische boek schreef. Ook naar de precieze inhoud van een vak als 'reclametekenen' of 'publiciteitskunst' aan de avondschool voor Kunstambachten in Antwerpen hebben we het raden. Het bewuste vak werd onder andere gedoceerd door Jos Léonard, een kunstenaar-ontwerper en Belgische pionier in het grafische ontwerp, maar in het onontsloten archief van de school werden geen documenten gevonden die iets prijsgeven over zijn pedagogie. Katrien Van Haute, "Jos Léonard en de ontstaansgeschiedenis van het grafisch ontwerp in België (1918-1936)" (Doctoraatsthesis, KU Leuven, 2009); Berchem, Stedelijke Academie voor Beeldende Kunsten Berchem \& Instituut Roger Avermaete, onontsloten archief.
8. "Schematische verhandeling over de kunstdrukschool Onze-LieveVrouw te Gent", Graphica: Maandelijks tijdschrift van de unie der grafische bedrijven en de boeknijverheid, oktober (1948), supplement.

9. Jan De Maeyer, red., De Sint-Lucasscholen en de neogotiek. 1862-1914 (Leuven, Universitaire pers, 1988), 8-9.

10. Zie voor de Nederlandse situatie het proefschrift van Jeroen van den Eijnde, Het huis van ik. Ideologie en theorie in het Nederlandse vormgevingsonderwijs (Arnhem: ArtEZ Press, 2015).

11. Wilfried Wouters. Van tekenklas tot kunstacademie: De Sint-Lucasscholen in België 1866-1966 (Kortrijk-Heule: UGA, 2013), 10-13.

12. Grafick had een grote bewondering voor de neogotische kunstenaarillustrator Charles Doudelet. Van hem verschenen enkele met houtsneden versierde pagina's (versierde boorden, illustraties en initialen) uit Beatrijs (Antwerpen, 1901) in: Grafiek, no. 5 (1938). Met de keuze voor een unciaal lettertype, verwant aan de Chaucer Type van William Morris, kan dit boek, uitgegeven en gedrukt door J.-E. Buschmann, beschouwd worden als een Belgische interpretatie van de Engelse Arts and Crafts-beweging. Véronique Latteur, Hilde Vercruysse en Chris Schoonejans, Charles Doudelet: illustrator (Gent, Arteveldehogeschool, 2007). Omdat Charles Doudelet geen uitgever vond voor zijn boek La beauté du livre (manuscript voltooid in 1912), koos hij er uiteindelijk voor om het in verschillende afleveringen te laten verschijnen in Grafiek (no. 2 (1937) - no. 21 (1946)). Naar het voorbeeld van de Arts and Crafts-beweging hechtte de auteur veel belang aan de kalligrafische voorgeschiedenis van lettertypes.

13. Er bestonden twee afdelingen: boekbinderij en drukkerij. De student doorliep twee voorbereidende jaren (een basisjaar en een oriënteringsjaar), kon zich vervolgens specialiseren gedurende één of twee jaar en de volgende einddiploma's halen: zetter, machinezetter, degeldrukker, persdrukker. "Schematische verhandeling".

14. Jan Peeters (broeder Zephirijn), "Kunt gij, zetter, u eigen troosten, met van tijd tot tijd een vondelingsken als eigen kind te begroeten, of wordt ge zon blije levensdrager: zetter-ontwerper?", Grafiek, no. 9 (1939).

15. KOLVO staat voor de afkorting van de oud-leerlingenbond (Kunstdrukschool Onze-Lieve-Vrouw Oud-leerlingenbond).

16. Het pas opgerichte tijdschrift Grafiek kreeg felicitaties van de redactie van La Chronique Graphique: "Un bel album", La Chronique Graphique, no. 90 (september 1937): 3615.

17. Philip Meggs, A History of Graphic Design (Harmondsworth, Viking, 1986), 300-309.

18. Baudin, "Het Belgische Boek", 291-330.

19. Jan Peeters (broeder Zephirijn), "Geest en stijl van Jos Léonard, grafieker en typograaf, rijkshoofdinspecteur bij het Technisch Onderwijs", Grafiek, no. 49 (1958); "Jos Léonard, veelzijdige grafische persoonlijkheid", Grafiek, no. 54 (1959).

20. De reconstructie van de vakbibliotheek van Jos Léonard is opgenomen als bijlage in: Van Haute, "Jos Léonard", bijlage 2.

21. Etablissementen Plantin was de belangrijkste letterleverancier van Grafiek. Dat weten we omdat de redactie trouw de gebruikte lettertypes in elk nummer vermeldde.

22. Geciteerd in: "Grafiek bedankt", Grafiek, no. 2 (1937).

23. In een latere lezersbrief van de directeur, Pierre Oly, wordt geen enkel punt van kritiek meer gegeven: 'Het was een lust om uw Paaschnummer van de Grafiek te beschouwen en den tekst te lezen. Wij maken U gaarne een bijzonder compliment voor de groote zorgen aan deze uitgave besteed ...' geciteerd in: "De Wereld in", Grafiek, no. 3 (1937).

24. "Een van de Oude Garde gaat heen ....", Grafiek, no. 8 (1939).

25. Meer uitgebreid hierover in het hoofdstuk 'Voorbeelddrukwerk voor Studio Plantin'. Van Haute, "Jos Léonard”, 297-343.

26. Léonard woog ook in pedagogische zin door op de Kunstdrukschool in zijn rol als inspecteur van het Technisch Onderwijs in België (benoemd in 1936 en later bevorderd tot hoofdinspecteur, wat hij tot aan zijn dood is gebleven). 
27. Jan Middendorp, Dutch Type (Rotterdam, o10 publishers, 2004), 48 .

28. De docenten uit de beginperiode waren Jan Evarist Peeters alias broeder Zephirijn; Willem Van Lommel alias broeder Hendrik en Jan Dierckx alias broeder Edwaard. De lekenleraars waren Chrispijn en Edgard de Buck, Charles van Houcke en Robert Heuvelmans. Erik Dekeyser, "Aan de Houtlei vroeger en nu", Ghendtsche Tydinghen. Tweemaandelijks Tijdschrift van de Heemkundige en Historische Kring Gent 22, no. 1 (1993): 204.

29. Jan Peeters, "Over typografie... en wat er mede te bereiken is", Grafiek, no. 16 (1943).

30. Wim D'Haveloose, Roland de Vuldere, Albert Le Clerq, Marc Raman, Erik Steuperaert, Jubileumboek ter herdenking van het 75-jarig bestaan van de Higro-campus: 1926-2001 (s.l., s.n., 2001): 22-23.

31. Jan Peeters (broeder Zephirijn), "Bij het tienjarig bestaan van een drukkerskern: KOLV en KOLVO”, Grafiek, nr. 20 (1946).

32. Mondelinge bron, Chris Schoonejans, oud-student, oud-docent van de Kunstdrukschool Onze-Lieve-Vrouw en conservator van het 'archief Grafische Bedrijven' van de Artevelde Hogeschool in Gent, maart 2016.

33. Jan Dierckx (broeder Edwaard), "Een Jubileum met Jubilarissen", Grafiek, no. 1 (1936).

34. Welke andere alternatieve woorden gebruikt werden alvorens het woord 'grafische vormgever' of 'grafische ontwerper' in België ingang vonden, wordt behandeld in: Van Haute, "Jos Léonard", 229-233.

35. Jan Peeters (broeder Zephirijn), “Ontwerpen?”, Grafiek, no. 4 (1937).

36. Peeters, "Over typografie...".

37. Wouters, Van tekenklas tot kunstacademie, 129-130.

38. Peeters, "zetter-ontwerper?".

39. "Schematische verhandeling".

4o. L. E. J.: "Bezoek aan onze vakscholen. De 'Kunstdrukschool OnzeLieve-vrouw' te Gent", Graphica. Maandelijks tijdschrift van de unie der grafische bedrijven en de boeknijverheid, oktober (1948), supplement.

41. Jan Peeters (broeder Zephirijn), "Zij-as-regelval”, Grafiek, no. 5 (1938)

42. Jan Peeters (broeder Zephirijn), "Zet-formules", Grafiek, no. 8 (1939).

43. De Sint-Lucaskunstenaars beschouwden de Belgische katholieke neogotiek als de ware erfgenaam van de Arts and Crafts-beweging en de Art Nouveau als een slechte kopie. Ellen van Impe, "De 'ware' erfgenamen van de Engelse Arts and Crafts. Neogotiek versus art nouveau in Belgische katholieke tijdschriften 1890-191" in Tekenen \& betekenen: opstellen over het architectuurinstituut Sint-Lucas 1862 - 2012, red. Rajesh Heynickx, Yves Schoonjans en Sven Sterken (Leuven: Lipsius, 2012), 109-121.

44. Mondelinge bron, Chris Schoonejans.

45. Peeters, "Zij-as regelval".

46. Wouters, Van tekenklas tot kunstacademie, 130.

47. Dick Dooijes, Over de drukletterontwerpen van Sjoerd H. de Roos (Zutphen: Bührmann-Ubbens, 1987), 15 .

48. Mondelinge bron, Chris Schoonejans.

49. Jan Peeters, "Over typografie...". Deze beschamend racistische uitspraak zegt veel over hoe sterk de tijdsgeest doordrongen was van het koloniale denken.

50. Nikolaus Pevsner, Pioneers of Modern Design. From William Morris to Walter Gropius (New York: Museum of Modern Art, 1949) [oorspr. Pioneers of the Modern Movement, 1936].

51. Christopher Wilk, Modernism (1914-1939). Designing a New World (Londen: V\&A Publications, 2006) 14.

52. Jan Peeters (broeder Zephirijn), "Niet twijfelen! De baan zwenkt, rechtdoor razen is zelfmoord", Grafiek, no. 18 (1945). In 1969 kon Jan Peeters echter niet meer om de figuur van Piet Mondriaan heen en gaf hem de nodige erkenning in: Jan Peeters, Algemene historisch gefundeerde grafische esthetica (Gent: HIGRO, 1969), 212-213. Zijn ontwerp in Mondriaanachtige stijl voor de cover van Grafiek, no. 61 (1962) kan ook als een eerbetoon gezien worden.
53. Vanaf jaargang 1929-1930 zijn de tijdschriften ingebonden. Het zou kunnen dat de oudere jaargangen met losse nummers later aan de bibliotheek werden geschonken. (Mondelinge bron, Chris Schoonejans).

54. Jan Tschichold, "Wege ins Neuland der Typographie", Deutscher Drucker, nr. 10 (1932): $43^{2-434}$

55. Jan Tschichold, Die neue Typographie, ein Handbuch für zeitgemäss Schaffende (Berlijn, Verlag des Bildungsverbandes der Deutschen Buchdrucker, 1928).

56. Alle 50oo exemplaren werden op een jaar tijd verkocht. Christopher Burke, Jan Tschichold and New Typography. Active Literature (Londen: Hyphen Press, 2007), 263.

57. Jan Tschichold and Charles Nypels. Typografische vormgeving (Amsterdam: Duwaer, 1938); Jan Tschichold, Typographische Gestaltung (Basel, Schwabe, 1935).

58. Vanaf 1938 concentreerde Jan Tschichold zich zelfs volledig op het boek. Hij keerde het reclameontwerp en zijn eigen dogma's van 'de nieuwe typografie' de rug toe en hij ontwierp zoveel mogelijk volgens een centrale as. Hij werd een liefhebber van precies datgene wat hij voordien verafschuwde: het symmetrische boek. Jan Tschichold, "Glaube und Wirklichkeit”, Schweizer Graphische Mitteilungen 65, no. 6 (1946).

59. Uiteindelijk zal Tschichold zich na de Tweede Wereldoorlog tegen de Nieuwe Typografie keren in een artikel tegen Max Bill, die hem anviel op zijn veranderde standpunt. Tschichold, "Glaube und Wirklichkeit".

6o. Burke, Jan Tschichold, 268.

61. Tschichold, Typografische vormgeving, 58. Aan het potloodschetsen wijdde hij eerder een volledige publicatie: Jan Tschichold, Typographische Entwurfstechniek (Stuttgart: Akademischer Verlag Dr. Fritz Wedekind, 1932).

62. Tschichold spreekt over het mengen van letters. Tschichold, Typografische vormgeving, 38,96 .

63. Tschichold, Typographische Gestaltung, 29, 52, 80.

64. Jan Peeters (broeder Zephirijn), "Wij zullen desnoods, als goochelaar, nieuwe uitzichten tooveren uit ons niet altijd nieuwe kassen, zoo we onszelf weten op te werken tot zetter-ontwerper", Grafiek, no. 10 (1940).

65. Peeters, "Niet twijfelen!".

66. Ibid.

67. Wilk, Modernism, 14 .

68. Het is geen toeval dat de Nederlandse vertaling werd gedrukt en uitgegeven door Frans Duwaer, een verzetsstrijder in Nederland die tijdens de Tweede Wereldoorlog duizenden valse documenten drukte en daar uiteindelijk de kogel voor kreeg. Alston Purvis, "In agris occupatis", Print 5o, no. 4 (1996).

69. Burke, Jan Tschichold, 268.

70. Gaston Durnez, Nieuwe encyclopedie van de Vlaamse Beweging,

(Tielt, Lannoo, 1998), 2777.

71. Peeters, "Zij-as regelval".

72. Ibid.

73. Wouters, Van tekenklas tot kunstacademie, 129.

74. "Hoe wordt een juist loonbarema vastgesteld? Waarderaming van den arbeid", Grafiek, no. 19 (1945).

75. Jozef Van Kerschaever, "Niet twijfelen!", Grafiek, no. 1 (1936).

76. Paul Greenhalgh, red., Modernism in Design, (Londen: Reaktion, 1990), 2-3.

77. Wilk, Modernism, 14-15.

78. Jan Peeters (broeder Zephirijn), "Een internationale typografische show. Verslag, conclusies en reproducties", Grafiek, no. 24 (1947). Grafiek berichtte regelmatig over dergelijke wedstrijden en tentoonstellingen, alleen is het jammer dat het vaak bleef bij een korte vermelding. Zoals ook gebeurde in 1937, wanneer de school blijkbaar het 'Diplome de grand prix' had weten te veroveren op de Parijse Exposition Internationale des Arts 
et des Techniques. Het bewuste diploma werd met enige trots gereproduceerd, maar niet van commentaar voorzien, noch geillustreerd met de gelauwerde ontwerpen. Reproductie 'Diplome de grand prix', Grafiek, no. 8 (1939).

79. De jury bestond uit: Ch. Graffard (afgevaardigd door Cristalleries du Val-Saint-Lambert); W. Tempermans (afgevaardigd door de Centrale der boeknijverheid, Brussel); J. Dallemangne (voorzitter en afgevaardigd door de Patronale kamer der grafische bedrijven, Luik); G. Dejace (secretaris en afgevaardigde van de Typografische studiekring, Brussel); J. Malaise (voorzitter en afgevaardigd voor de Vereniging van de grafische kunsten, Luik); V. Fréderickx (afgevaardigd door de Meesters-drukkers, Luik); J. Beaujean (afgevaardigd door de jubilerende associatie).

8o. Met een rastercliché of autotypie was het sinds 1880 mogelijk om foto's om te zetten naar hoogdruk. Van een foto werd een negatieve fotografische opname gemaakt (op glas of film) en via dit negatief werd een fotogevoelige plaat belicht en geëtst. Om grijze tonen in hoogdruk te reproduceren werd de drukplaat belicht via een raster. Door het raster werd de drukvorm opgedeeld in een structuur van minuscule puntjes, die groter waren naarmate de grijze toon donkerder was en kleiner naarmate ze een lichtere indruk moesten geven. Karel F. Treebus, Vormwijzer, een gids bij het vormgeven en produceren van drukwerk ('s-Gravenhage: SDU, 1996), 42-43. Het cliché werd op een houten of loden blok genageld of geplakt en ging samen met de tekst onder de pers. Fernand Baudin, "België 1920-1980", in: Fernand Baudin. Typograaf. Bibliografie van zijn geschriften. Inventaris van het typografisch oeuvre, red. Elly Cockx-Indestege, Georges Colin en Fernand Baudin (Amsterdam: De Buitenkant, 2002), 83 .

81. Raisin is een oud Belgisch papierformaat van $500 \times 650 \mathrm{~mm}$. Kwarto $\left(4^{\circ}\right)$ betekent tweemaal gevouwen, dus $4^{\circ}$ Raisin is een formaat van $250 \mathrm{x}$ $325 \mathrm{~mm}$ (schoon gesneden ongeveer $246 \times 320 \mathrm{~mm}$ ).

82. Het Italiaans ontwerp (de naam van de ontwerper is niet vermeld) dat om deze reden werd geweigerd, is als laatste afgebeeld in het artikel.

83. Peeters, "Een internationale typografische show".

84. Wanneer Nazi-Duitsland al ter sprake kwam, was dat op een zakelijke toon in een tekstje van Jan Peeters, waarin een feitelijk overzicht werd gegeven van alle mogelijke kruisen en hun historisch culturele achtergrond. In dit overzicht kwam ook het hakenkruis aan bod: 'Als actualiteit, maar buiten elk passieverband, één der zooveel overige kruisvormen: het hakenkruis. (...) Met de haken rechts van den opgaanden arm afgewend is het een teeken ten goede; andersom, heet het sauwastika, en is het een teeken ten kwade. Het komt zittend en statisch voor of bewegend en dynamisch, zooals het huidige Hitlerkruis. In dit laatste hedendaagsch geval, heeft het echter geen godsdienstige beteekenis.' Jan Peeters (broeder Zephirijn), "Zetter-ontwerper", Grafick, no. 11-12 (1940).

\section{BIOGRAPHY}

Katrien van Haute (1977) is als docent verbonden aan LUCA School of Arts (campus Gent) en gedoctoreerd in de Kunstwetenschappen (KU-Leuven) met een studie over de ontstaansgeschiedenis van het grafisch ontwerp en de moderne typografie in België tijdens het interbellum.

\section{KEYWORDS}

- Tijdschrift Grafiek

- Katholieke Grafische Vormgeving

- Typografie

- Modernisme

- Jan Peeters (broeder Zephirijn)

- Sint-Lucas onderwijs 